\title{
The potential of memorial tourism development in Istria (Croatia)
}

\author{
Potencijali razvoja memorijalnog turizma \\ u Istri (Hrvatska)
}

This paper analyses the geographical features and potential of memorial tourism development in the tourism region of Istria in Croatia. In the past century, Istria has had several political and socio-economic turning points, with far-reaching consequences for its overall development. For the most part, the historical turning points in the $20^{\text {th }}$ century in Istria were marked by armed conflict, followed by individual and mass human casualties, terror, and the persecution of the population. The motive of travel in memorial tourism here is to visit the places where these tragic events occurred. Therefore, the aim of this research was to determine the geographical distribution of potential sites in Istria suitable for the development of memorial tourism. An additional objective was to propose thematic routes of memorial tourism in the areas of Istrian towns and municipalities. A secondary aim of this research was to provide a geographical contribution to the scientific evaluation of memorial tourism in Croatian tourism regions, with proposals for measures in the planning of the development of this form of tourism.

Key words: memorial tourism, sites, thematic routes, Istria
U ovom su radu analizirane geografske značajke i potencijali razvoja memorijalnoga turizma u hrvatskoj turističkoj regiji Istra. U prošlom stoljeću Istra je prolazila kroz nekoliko političkih i socioekonomskih prekretnica s dalekosežnim posljedicama za njezin cjelokupni razvoj. Povijesne prijelomnice u Istri u 20. stoljeću najvećim su dijelom obilježene oružanim sukobima praćenim pojedinačnim i masovnim ljudskim žrtvama, progonima i terorom nad stanovništvom. Posjećivanje mjesta takvih tragičnih događaja motiv su putovanja u memorijalnom turizmu. Cilj istraživanja jest utvrditi geografski raspored potencijalnih lokaliteta u Istri pogodnih za razvoj memorijalnoga turizma. Dodatni je cilj predložiti tematske rute memorijalnoga turizma na područjima istarskih gradova i općina. Svrha je istraživanja pružiti geografski doprinos znanstvenom vrednovanju memorijalnoga turizma u hrvatskim turističkim regijama, uz prijedloge mjera za planiranje razvoja ovoga oblika turizma.

Ključne riječi: memorijalni turizam, lokaliteti, tematske rute, Istra 
HRVATSKI

GEOGRAFSKI

GLASNIK

82/2, 107-129 (2020.)

\section{Introduction}

The region of Istria is the top tourist region in the Republic of Croatia, due to its favourable geographic location in relation to the emissive regions of Central and Western Europe and its diverse natural and anthropogenic tourist attractions. According to the Croatian Bureau of Statistics (2019), one-fourth of tourist beds were registered in commercial accommodation facilities in Istria in 2018, one-quarter of total tourist arrivals, and almost onethird of total tourist overnight stays in the Republic of Croatia ${ }^{1}$. Ten of the 25 top tourist destinations in Croatia, according to the total number of tourist overnight stays, are located in Istria.

The geographical layout of tourism in Istria indicates a large concentration in coastal towns and municipalities and similarly, tourist arrivals and overnight stays have an extreme seasonal concentration in the summer months, reflecting the consequences of the "Sun and Sea" tourism development model adapted to stationary, summer tourism and the holiday season, including the school holidays in nearby emissive regions and states (Ivandić et al.,2006; Afrić Rakitovac et al.,2019). In order to extend the tourist season from summer months into a year-round season and to develop the inner micro-regions of Istria, the strategic document the 2015-2025 Master Plan for Tourism in Istria County suggests special interest tourism such as rural, sports, event, and cultural tourism (Istria Tourist Board, 2014). Related to the main strategic goals of the aforementioned Master Plan, tourist promoters, agents, and local tourist boards have been trying to implement many subtypes of cultural tourism over the last twenty years. Among these, heritage tourism and the revival of folk traditions have been distinguished as the most important (Ružić and Medica, 2010; Gržinić and Vodeb, 2015; Afrić Rakitovac and Urošević, 2017; Orlić, 2019). On the other hand, some sub-types of cultural tourism such as memorial tourism are completely neglected in Istria's tourism supply. This state of neglect was the main motive for this research and, consequently, the main objective of this paper was to identify the geographical features and potentials

\footnotetext{
1 The tourism region of Istria is geographically equated with the regional self-government unit of Istria County (Croatia) which consists of 10 towns and 31 municipalities.
}

Uvod

Regija Istra zbog svoga povoljnog geografskog položaja u odnosu na emitivne regije Srednje i Zapadne Europe te raznolikih prirodnih i antropogenih turističkih atrakcija postala je vodeća turistička regija u Republici Hrvatskoj. Prema Državnom zavodu za statistiku (2019.), u Istri je u 2018. godini bila registrirana četvrtina turističkih ležaja u objektima za komercijalni smještaj, ostvarena je četvrtina ukupnih dolazaka turista i gotovo trećina ukupnih turističkih noćenja Republike Hrvatske. ${ }^{1}$ Deset od 25 vodećih turističkih destinacija prema ukupnom broju noćenja turista nalazi se u Istri.

Geografski raspored turizma u Istri upućuje na veliku koncentraciju u obalnim gradovima i općinama, a slično tomu, turistički dolasci i noćenja imaju ekstremnu sezonsku koncentraciju u ljetnim mjesecima, što odražava posljedice turističkoga razvojnog modela Sunce i more koji je prilagođen stacionarnom, ljetnom turizmu te sezoni godišnjih odmora, uključujući školske praznike u obližnjim emitivnim regijama i državama (Ivandić i dr., 2006.; Afrić Rakitovac i dr., 2019). Kako bi se turistička sezona iz ljetnih mjeseci proširila u cjelogodišnju i razvile unutrašnje mikroregije Istre, u strateškom dokumentu Master plan turizma Istarske županije 2015 - 2025. predlažu se posebni oblici turizma poput ruralnoga, sportskoga, manifestacijskoga i kulturnoga turizma (Turistička zajednica Istre, 2014). Povezano s glavnim strateškim ciljevima Master plana turistički promotori, agenti i lokalne turističke zajednice u posljednjih dvadeset godina u Istri pokušavaju implementirati mnoge podoblike kulturnoga turizma. Među njima se kao najvažniji izdvajaju baštinski turizam te oživljavanje narodnih tradicija (Ružić i Medica, 2010; Gržinić i Vodeb, 2015; Afrić Rakitovac i Urošević, 2017; Orlić, 2019). S druge strane, neki su podoblici kulturnoga turizma, poput memorijalnoga turizma, u potpunosti zanemareni u turističkoj ponudi Istre. Takva zanemarenost bila je najvažniji motiv ovoga istraživanja te se prema tome kao glavni cilj

\footnotetext{
1 Turistička regija Istra geografski je izjednačena s jedinicom regionalne samouprave Istarske županije (Hrvatska) koja se sastoji od 10 gradova i 31 općine.
} 
of memorial tourism, including the geographical distribution of the sites in Istria suitable for memorial tourism development. Additionally, a secondary goal of this research was to propose thematic routes of memorial tourism in the territories of Istrian towns and municipalities.

In the past century, Istria has had several political and socio-economic turning points, as well as ground-breaking events and processes with far-reaching consequences for its overall development. These political and socio-economic turning points, as well as the historical ground-breaking events and processes in Istria were for the most part marked by wars and other armed conflicts followed by individual and mass human casualties, as well persecution and atrocities committed against individuals and the population. Historically, these events and processes in Istria were mostly in the first half of the $20^{\text {th }}$ century (Drndić, 1978; Dukovski, 2001; 2011a; Mikolić, 2003; Giron, 2004; Buršić, 2011). It is for this reason that the historical framework for the study of memorial tourism in Istria is limited to tragic events from the beginning of World War I (WWI) to the end of World War II (WWII), including the immediate post-WWII period.

\section{Theoretical framework: memorial or dark tourism in Istria?}

In this research, memorial tourism is considered to be visits and stays in locations of individual and mass casualties caused by war and other armed conflicts, excluding casualties caused by natural disasters, or industrial and traffic accidents (Opačić, 2003; Kesar and Tomas, 2014; Hertzog, 2014; González Vázquez, 2018). As Kesar and Tomas (2014) argue in scientific literature, memorial tourism is a syntagma that occurs relatively rarely, and its use is greatest in the number of cases associated with tourist visits to sites in memory of the mass casualties of major armed conflicts and political persecution. The same authors emphasised narrower thematic coverage and made a comparison with dark tourism, thus excluding individual burial sites, sites of morbid religious rituals, and obscure places designed for mystical events, the purpose of which was primarily fun and entertainment. How- rada izdvaja identificiranje geografskih obilježja i potencijala memorijalnoga turizma, uključujući geografski raspored lokaliteta u Istri pogodnih za razvoj memorijalnoga turizma. Osim toga, cilj je istraživanja predložiti tematske rute memorijalnoga turizma na područjima istarskih gradova i općina.

U prošlom stoljeću Istra je prolazila kroz nekoliko političkih i društveno-ekonomskih prekretnica i prijelomnih događaja i procesa koji su imali dalekosežne posljedice na njezin cjelokupni razvoj. Političke i društveno-ekonomske prekretnice i povijesni prijelomni događaji i procesi u Istri najvećim su dijelom obilježeni ratnim i drugim oružanim sukobima praćenim pojedinačnim i masovnim ljudskim žrtvama, progonima i zločinima nad pojedincima i stanovništvom. Ti su događaji i procesi u Istri koncentrirani u prvoj polovici 20. stoljeća (Drndić, 1978; Dukovski, 2001; 2011a; Mikolić, 2003; Giron, 2004; Buršić, 2011) pa je zbog toga povijesni okvir za istraživanje memorijalnoga turizma u Istri ograničen na tragične događaje od početka Prvoga svjetskog rata do kraja Drugoga svjetskog rata uključujući njegovo neposredno poslijeratno razdoblje.

\section{Teorijski okvir: memorijalni ili mračni łurizam u Istri?}

U ovom se istraživanju memorijalni turizam definira kao posjet i boravak u mjestima pojedinačnih i masovnih žrtava uzrokovanih ratom i drugim oružanim sukobima, isključujući žrtve prirodnih katastrofa, industrijskih i prometnih nesreća (Opačić, 2003; Kesar i Tomas, 2014; Hertzog, 2014; González Vázquez, 2018). Kesar i Tomas (2014) utvrdili su da se u znanstvenoj literaturi sintagma memorijalni turizam relativno rijetko pojavljuje te da se njegova upotreba u najvećem broju slučajeva povezuje s turističkim posjetima lokalitetima u znak sjećanja na masovne žrtve velikih oružanih sukoba i političkoga progona. Nadalje, isti autori naglašavaju uži tematski okvir memorijalnoga turizma u usporedbi s mračnim turizmom isključujući iz njegova opsega pojedinačna grobišta i groblja, mjesta morbidnih obreda u vjerske svrhe, opskurna mjesta s mističnim događajima organiziranima u svrhu provoda i za-
The potential of memorial tourism development in Istria (Croatia)

Potencijali razvoja memorijalnog turizma u Istri (Hrvatska) 
GEOGRAFSKI

GLASNIK

82/2,107-129 (2020.) ever, the individual places of death or burial sites of historical personages that are included in this research are a part of the collective memory and identity in Istria, and the local population is still deeply connected to these historical figures and their tragic fates ${ }^{2}$.

Concerning the theoretical fragility and eclecticism of dark tourism literature (Stone, 2006), there are three major divergences between dark and memorial tourism which are relevant to this research. Primarily, dark tourism includes locations of death, disasters, and atrocities (Foley and Lennon, 1996). Nevertheless, dark tourism, in comparison to memorial tourism, has a broader network of tourist sites, attractions and exhibitions including locations, and attractions associated with fun and entertainment (Stone, 2006; Stone and Sharpley, 2008; Bowman and Pezzullo, 2009; Stone, 2012; Mionel, 2019). Secondly, as González Vázquez (2018) noted, memorial tourism was implemented soon after World War I by tourist agents and organisations that promoted battlefields in northeastern France, and this included memorial heritage. Dark tourism, according to the same author, was created and promoted in the academic field covering a broader spectrum of locations and dissonant heritage (Tunbridge and Ashworth, 1996; Nauert, 2017) ${ }^{3}$.

Finally, and most importantly, an aspect part of dark tourism classified as dark fun factories (Stone, 2006; Raine, 2013) is inappropriate and the establishment of such in Istria and Croatia is not possible. The tragic events of the $20^{\text {th }}$ century, which make up the historical framework of this research, are still in the living memory of the local population who commemorate its victims regularly. These locations and commemorative events are a part of national identity and are linked to the descendants of the victims and those who wish to pay their respects even today (Dukovski, 2001; Opačić, 2003; Kesar and Tomas, 2014; Drvenkar et al., 2015; Šuligoj, 2016; Vukojević and Opačić, 2017). Likewise,

2 For example, every year descendants and local officials of the Town of Pula and Istria County lay flowers at the monument to Vladimir Gortan (1904-1929) in Gortan Cove, a combatant against fascism who was executed there in 1929.

3 Dissonant heritage is heritage that recalls past events not easily reconciled to the values and everyday experiences of contemporary visitors (Cortini, 2019). bave. Međutim, pojedinačna mjesta smrti ili ukopa povijesnih osoba uključena su u ovo istraživanje jer su dio kolektivne memorije i nacionalnoga identiteta u Istri, a lokalno je stanovništvo još uvijek duboko povezano s tim povijesnim osobama i njihovim tragičnim sudbinama. ${ }^{2}$

Uvažavajući teorijsku fragilnost i eklekticizam literature o mračnom turizmu (Stone, 2006), postoje tri glavne razlike u opsegu mračnoga i memorijalnoga turizma koje su relevantne za ovo istraživanje. Primarno, mračni turizam povezan je s lokalitetima smrti, katastrofa i zvjerstava (Foley i Lennon, 1996). Ipak, mračni turizam u odnosu na memorijalni turizam ima širu mrežu turističkih lokaliteta, atrakcija i izložaba, uključujući lokacije i atrakcije povezane sa zabavom i provodom (Stone, 2006; Stone i Sharpley, 2008; Bowman i Pezzullo, 2009; Stone, 2012; Mionel, 2019). Kao drugo, a što je u svom radu naglasio González Vázquez (2018), memorijalni turizam stvorili su netom nakon Prvoga svjetskog rata turistički agenti i organizacije koje su promovirale mjesta bitaka na sjeveroistoku Francuske, a uključivao je memorijalnu baštinu. Mračni turizam, prema istom autoru, stvoren je i promoviran od akademske zajednice pokrivajući širi spektar lokacija i disonantnu baštinu (Tunbridge i Ashworth, 1996; Nauert, 2017). ${ }^{3}$

Konačno i najvažnije, dio spektra mračnoga turizma klasificiran kao tvornice mračne zabave (Stone, 2006; Raine, 2013) nije prikladan te se ne bi mogao primijeniti u Istri i Hrvatskoj za tragične povijesne događaje iz 20. stoljeća. Naime, tragični događaji u 20. stoljeću koji su povijesni okvir ovoga istraživanja još uvijek su u svježem sjećanju lokalnoga stanovništva koje redovito odaje počast žrtvama. Te su lokacije i komemorativni događaji i danas dio nacionalnoga identiteta te su vezani za potomke i štovatelje žrtava (Dukovski, 2001; Opačić, 2003; Kesar i Tomas, 2014.; Drvenkar i dr., 2015; Šuligoj, 2016; Vukojević i Opačić, 2017). Isto tako, kulturna baština memorijalnoga (mračnoga) turizma u $\mathrm{Hr}$ -

\footnotetext{
2 Primjerice, svake godine potomci, lokalni dužnosnici Grada Pule i Istarske županije polažu cvijeće na spomenik borcu protiv fašizma Vladimiru Gortanu (1904. - 1929.) u Gortanovoj uvali, gdje je pogubljen 1929. godine.

3 Disonantna baština je baština koja podsjeća na prošle događaje koje nije lako pomiriti s vrijednostima posjetitelja i svakodnevnim iskustvom (Cortini, 2019)
} 
the cultural heritage for memorial (dark) tourism in Croatia and Istria requires good and sensible management and quality interpretation on site (Dujmović, 2019). For the same reasons, the locations in this paper cannot be termed tourist attractions, rather as memorial sites (Seaton 2002; Sharpley and Stone 2009).

\section{An overview of previous research and methodology}

Dark and memorial tourism as part of the larger cultural tourism umbrella has attracted tourists for many decades and consequently has led to increasing interest among researchers and scholars in tourism studies, economics, geography, anthropology, psychology, history, sociology, ethnology, and other fields. Thus, authors of scientific and professional papers, books and other publications have been researching dark and memorial tourism from various scientific viewpoints. Rojek's book Ways of Escape (1996), which included the term "Black spot", is mentioned as the first scientific explanation of dark and memorial tourism sites. In the initial research period, the most important papers, definitions, theoretical concepts, practices (Folley and Lennon, 1996; Lennon and Folley, 2000; Wight, 2006; Stone and Sharpley, 2008; Sharpley and Stone, 2009) and historical development of dark tourism (Seaton, 1996) came into consideration. However, papers dealing with the supply side expressed through the dark tourism spectrum (Stone, 2006; Raine, 2013), the new directions in research (Hartmann, 2014; Mionel 2019) and dark and memorial tourism theoretical models and divergences (González Vázquez, 2018), are the most important.

There are numerous examples of European tourist regions that include sites of individual and mass casualties in their tourism supply, such as the locations of major battles of World War I and burial grounds in France, Belgium, and Italy (Seaton, 2000; Winter, 2011; Irimiás, 2014; Virgili et al., 2018), as well as monuments and museums dedicated to the victims of Nazism in Berlin, Dachau, and Auschwitz (Wollaston, 2005; Brown, 2015; Liyanage et al., 2015). vatskoj i Istri zahtijeva dobro i razumno upravljanje te kvalitetnu interpretaciju na licu mjesta (Dujmović, 2019). Iz navedenih razloga potencijalni lokaliteti razmatrani u ovom radu ne bi mogli biti imenovani i označeni kao turističke atrakcije, već kao memorijalni i komemorativni lokaliteti (Seaton 2002; Sharpley i Stone 2009).

\section{Pregled dosadašnjih istraživanja i metodologija}

Mračni i memorijalni turizam kao dio širokoga spektra kulturnoga turizma privlačio je turiste već desetljećima i posljedično povećavao interese i znanstvenu znatiželju među istraživačima i znanstvenicima turističkih studija, ekonomije, geografije, antropologije, psihologije, povijesti, sociologije, etnologije i drugih. Dakle, autori su u znanstvenim i stručnim radovima, knjigama i drugim publikacijama proučavali mračni i memorijalni turizam $\mathrm{s}$ raznorodnih znanstvenih stajališta. Rojekovu knjigu Ways of Escape (1996) i izraz Black Spot mnogi su autori spomenuli kao prvo znanstveno tumačenje mračnih i memorijalnih turističkih lokaliteta. U prvom istraživačkom razdoblju najvažniji radovi razmatrali su definicije, filozofske i teorijske koncepte i prakse (Folley i Lennon, 1996; Lennon i Folley, 2000; Wight, 2006; Stone i Sharpley, 2008; Sharpley i Stone, 2009) te povijesni razvoj mračnoga turizma (Seaton, 1996). Ipak, za ovo su istraživanje najvažniji radovi o turističkoj ponudi izraženi spektrom mračnoga turizma (Stone, 2006; Raine, 2013), novim pravcima istraživanja (Hartmann, 2014; Mionel 2019) i teorijskom modelu i razlikama između mračnoga i memorijalnoga turizma (González Vázquez, 2018).

Brojni su primjeri europskih turističkih regija koje u svojoj turističkoj ponudi uključuju mjesta pojedinačnih i masovnih žrtava, poput mjesta velikih bitaka iz Prvoga svjetskog rata i groblja u Francuskoj, Belgiji i Italiji (Seaton, 2000; Winter, 2011; Irimiás, 2014; Virgili i dr., 2018.) ili spomenika i muzeja žrtava nacizma u Berlinu, Dachauu i Auschwitzu (Wollaston, 2005; Brown, 2015; Liyanage i dr., 2015).
The potential of memorial tourism development in Istria (Croatia)

Potencijali razvoja memorijalnog turizma u Istri (Hrvatska) 
In countries that share a similar line of historical development throughout the $20^{\text {th }}$ century and similar political and socio-economical turning points like Croatia, there have also been ideas of creating and developing a complex memorial tourism supply and thematic routes at the national level: such is the case in Slovakia (Horodnikova and Derco, 2015), Romania (Ghetau and Esanu, 2010), Serbia (Minić, 2012), and Slovenia (Šuligoj, 2017a). The first mention of the term memorial tourism in Croatian scientific literature, yet lacking an exact definition, was in a linguistic journal by Kalmeta (1981). Nevertheless, the most significant scientific papers and publications on memorial tourism in Croatia concern possibilities of development; these include Homeland War (the 1991-1995 Croatian War of Independence) heritage (Opačić, 2003; Drvenkar et al., 2015), Goli Otok (a political prison during the communist regime), the WWII concentration camp Jasenovac, and the City of Vukovar (Kesar and Tomas, 2014; Vukojević and Opačić, 2017; Kennel et al., 2018), as well as the great potential for war tourism (Šuligoj, 2016; 2017b).

In order to obtain results and realise research goals, several scientific methods and techniques were used. The first stage of this research included analyses of historical research, scientific papers, books and other publications regarding the tragic events in the first half of the $20^{\text {th }}$ century in Istria and the most significant turning points in this period (Drndić, 1978; Cherin, 1993; Dukovski, 2001; 2011a; 2011b; Mikolić, 1973; 2003; Giron, 2004; Scotti, 2008; Pirjevec, 2009; Radošević, 2009; Buršić, 2011; Kešac and Skuljan Bilić, 2018). Using such research and related publications, the tragic events in Istria in first half of the $20^{\text {th }}$ century were divided into three historical periods: the World War I (WWI) period; the interwar period; and the World War II (WWII) period-including the immediate post-WWII period. This stage also included analyses of Istrian town and municipality official websites, including local tourism board websites and an Istrian culture website (istria-culture.com). The purpose of website analysis was to find information on the use of potential memorial tourism sites as places for commemorative events (Kennel et al., 2018; Šuligoj, 2019).
U državama koje su po svom povijesnom razvoju te političkim i socioekonomskim prijelomnicama u 20. stoljeću slične Hrvatskoj postoje ideje o stvaranju i razvoju kompleksne ponude tematskih ruta memorijalnoga turizma na nacionalnoj razini poput Slovačke (Horodnikova i Derco, 2015), Rumunjske (Ghetau i Esanu, 2010), Srbije (Minić, 2012) i Slovenije (Šuligoj, 2017a). Prvo spominjanje pojma memorijalni turizam u hrvatskoj znanstvenoj literaturi, ali bez točne definicije, objavio je Kalmeta (1981) u jezikoslovnom časopisu. Ipak, najvažniji znanstveni radovi i publikacije o memorijalnom turizmu u Hrvatskoj odnose se na mogućnosti razvoja, uključujući baštinu iz Domovinskoga rata (Opačić, 2003; Drvenkar i dr., 2015.), politički zatvor komunističkoga režima na Golom otoku, koncentracijski logor Jasenovac iz Drugoga svjetskog rata te grad Vukovar (Kesar i Tomas, 2014; Vukojević i Opačić, 2017; Kennel i dr., 2018) te potencijal ratnoga turizma u Hrvatskoj (Šuligoj, 2016; 2017b).

Nekoliko znanstvenih metoda i tehnika upotrijebljeno je u svrhu postizanja rezultata i ostvarivanja ciljeva istraživanja. Prva faza istraživanja uključivala je analizu povijesnih istraživanja, znanstvenih radova, knjiga i drugih publikacija o tragičnim događajima u prvoj polovici 20. stoljeća u Istri te najznačajnijim povijesnim prekretnicama u tom razdoblju (Drndić, 1978; Cherin, 1993; Dukovski, 2001; 2011a; 2011b; Mikolić, 1973; 2003; Giron, 2004; Scotti, 2008; Pirjevec, 2009; Radošević, 2009; Buršić, 2011; Kešac i Skuljan Bilić, 2018). Koristeći se tim istraživanjima i publikacijama, tragični događaji u Istri u prvoj polovici 20. stoljeća klasificirani su u tri povijesna razdoblja: razdoblje Prvoga svjetskog rata, međuratno razdoblje i Drugi svjetski rat uključujući njegovo neposredno poraće. Također su u toj fazi istraživanja analizirane službene mrežne stranice istarskih općina i gradova, mrežne stranice lokalnih turističkih zajednica i mrežne stranice Istarska kultura (istria-culture.com). Svrha analize mrežnih stranica jest pronalaženje obavijesti i podataka o korištenju potencijalnih memorijalnih turističkih lokaliteta kao mjesta komemorativnih događaja (Kennel i dr., 2018; Šuligoj, 2019). 
Tab. 1 Dark tourism suppliers and typology of the sites for memorial tourism in Istria Tab. 1. Ponuda mračnog turizma i tipologija lokaliteta memorijalnog turizma u Istri

\begin{tabular}{|c|c|}
\hline $\begin{array}{l}\text { Dark tourism suppliers (Stone, 2006) } \\
\text { / Ponuda mračnog turizma }\end{array}$ & $\begin{array}{l}\text { Typology of sites for memorial tourism in Istria } \\
\text { / Tipologija lokaliteta memorijalnog turizma u Istri }\end{array}$ \\
\hline $\begin{array}{l}\text { Dark Fun Factories } \\
\text { / Tvornice mračne zabave }\end{array}$ & - \\
\hline $\begin{array}{l}\text { Dark Exhibitions } \\
\text { / Mračne izložbe }\end{array}$ & $\begin{array}{l}\text { Memorial exhibitions and museums } \\
\text { / Memorijalne izložbe i muzeji }\end{array}$ \\
\hline $\begin{array}{l}\text { Dark Dungeons } \\
\text { / Mračne tamnice }\end{array}$ & $\begin{array}{l}\text { Places of internment: prisons and camps } \\
\text { / Mjesta zatočeništva: Zatvori i logori }\end{array}$ \\
\hline $\begin{array}{l}\text { Dark Resting Places } \\
\text { / Mračna počivališta }\end{array}$ & $\begin{array}{l}\text { Cemeteries } \\
\text { / Groblja }\end{array}$ \\
\hline $\begin{array}{l}\text { Dark Shrines } \\
\text { / Mračna svetišta }\end{array}$ & $\begin{array}{l}\text { Places of death or burial of historical personage } \\
\text { / Mjesta smrti ili pokopa povijesnih osoba }\end{array}$ \\
\hline $\begin{array}{l}\text { Dark Conflict Sites } \\
\text { / Mračna mjesta sukoba }\end{array}$ & $\begin{array}{l}\text { Battles and armed conflicts } \\
\text { / Bitke i oružani sukobi }\end{array}$ \\
\hline $\begin{array}{l}\text { Dark Camps of Genocide } \\
\text { / Mračni logori smrti }\end{array}$ & $\begin{array}{l}\text { Mass casualties of population } \\
\text { / Masovna stradavanja stanovništva }\end{array}$ \\
\hline
\end{tabular}

The potential of memorial tourism development in Istria (Croatia)

Potencijali razvoja memorijalnog turizma u Istri (Hrvatska)
During the second stage of this research, visits and observations of potential sites for memorial tourism were made; these were analysed and highlighted in the historical literature, with fieldwork; and participant observation methods as defined by Halmi (2005), Hall (2011), de Walt and de Walt (2011), Ribeiro and Foemmel (2012), Phillips and Johns (2012) were also put to use. Fieldwork and participant observation lasted 14 months: October 2018 to December 2019. During this period, visits and observations of potential sites for memorial tourism in towns and municipalities throughout Istria were made 4 . Simultaneously, fieldwork and participant observation methods were included with mapping and photo documentation (Jacobsen, 2007; Rakić and Chambers, 2012; Brown 2015; Vojnović, 2016). All the visited potential sites for memorial tourism were classified using a modified typology of a dark suppliers list (dark tourism product) as presented and published by Stone (2006). A modified and adapted typology of the sites for memorial tourism in Istria includes six potential types (Tab. 1).

\footnotetext{
4 The potential sites for memorial tourism that were observed were local cemeteries, burial grounds, and the places of death of historical personages, places of battles and other armed conflicts, museums, memorial exhibitions, karst pits, bauxite pits, and settlements (rural and urban) where mass casualties of the population occurred.
}

Tijekom druge faze ovoga istraživanja posjećivali su se potencijalni lokaliteti memorijalnoga turizma koji su obrađeni i istaknuti u povijesnoj literaturi služeći se istovremeno metodom terenskoga istraživanja i metodom sudioničkoga promatranja kako su definirali Halmi (2005), Hall (2011), de Walt i de Walt (2011), Ribeiro i Foemmel (2012) te Phillips i Johns (2012). Terensko istraživanje i sudioničko promatranje trajalo je 14 mjeseci i to od listopada 2018. do prosinca 2019. godine. Tijekom toga razdoblja posjećeni su potencijalni lokaliteti memorijalnoga turizma u svim istarskim gradovima i općinama. ${ }^{4}$ Istovremeno se metode terenskoga istraživanja i sudioničkoga promatranja upotrebljavaju zajedno s tehnikom kartiranja i fotografskoga dokumentiranja (Jacobsen, 2007; Rakić i Chambers, 2012; Brown 2015; Vojnović, 2016). Svi posjećeni potencijalni lokaliteti memorijalnoga turizma klasificirani su uporabom modificirane tipologije ponude mračnoga turizma (proizvod mračnoga turizma) koju je predstavio i objavio Stone (2006). Izmijenjena i prilagođena tipologija lokaliteta za memorijalni turizam u Istri uključuje šest potencijalnih tipova (tab. 1).

\footnotetext{
4 Posjećeni potencijalni lokaliteti za memorijalni turizam bila su lokalna groblja, mjesta pogibije i grobovi povijesnih osoba, mjesta bitaka i drugih oružanih sukoba, muzeji, spomen-izložbe, krške jame, boksitne jame te naselja (ruralna i urbana) u kojima su se dogodila masovna stradavanja stanovništva.
} 
In the final stage of research, the data generated through fieldwork, participant observation, mapping, and photo documentation were used to compile and propose a list of potential memorial tourism sites as the main points of thematic routes similar to the examples of good practices in Slovenia (Soča Valley), Romania, Italy, and Slovakia (Ghetau and Esanu, 2010; Tizzoni, 2013; Irimiás, 2014; Horodnikova and Derco, 2015; Nauert, 2017; Šuligoj, 2017b)

\section{Results and discussion}

Using the proposed research methods and techniques as well as the established historical periodisation of the first half of the $20^{\text {th }}$ century, all six types of potential memorial tourism sites were found in Istria. These potential sites are evenly distributed throughout Istrian towns and municipalities.

Potential memorial tourism sites associated with the tragic events of World War I are mostly distributed in and around the town of Pula, which was the main Austro-Hungarian naval port and military base in which numerous battleships were anchored until the very end of WWI. The most important site in Pula is the Naval Cemetery in which approximately 150,000 soldiers and civilians are buried, encompassing the span of a century (18621960), among them several Austro-Hungarian admirals. The Naval Cemetery is also the final resting place of the civilian and military victims of WW1 and WW2; among the most interesting is the memorial to the Austrian/Croatian admiral Janko Vuković Podkapelski and the tomb of Nazario Sauro, an Austrian-born Italian patriot and sailor executed in Pula by Austrian authorities 5 . Other sites in Pula associated with WWI are the monument to the sinking of the battleship Viribus Unitis (parts of which were removed from the seabed of the port of Pula and transferred to Italian museums) and a monument to rebel sailors in a nearby park. Both monuments are in the central coastal part of the port of Pula. Austro-Hungarian fortresses, as part

5 The remains of Nazario Sauro (1880-1916) were moved from Pula to Venice after WWII and his tomb is now empty, but it is regularly visited and decorated with flowers.
U posljednjoj fazi istraživanja, podaci prikupljeni analizom povijesne literature, terenskim istraživanjem, sudioničkim promatranjem, kartiranjem i fotografskim dokumentiranjem koriste se za sastavljanje i prijedlog popisa potencijalnih memorijalnih turističkih lokaliteta kao glavnih punktova tematskih ruta slično primjerima dobre prakse u Sloveniji (dolina Soče), Rumunjskoj, Italiji i Slovačkoj (Ghetau i Esanu, 2010; Tizzoni, 2013; Irimiás, 2014; Horodnikova i Derco, 2015; Nauert, 2017; Šuligoj, 2017b).

\section{Rezultati i rasprava}

Pomoću predloženih istraživačkih metoda i tehnika, kao i utvrđene povijesne periodizacije prve polovice 20. stoljeća, u Istri je pronađeno svih šest tipova potencijalnih memorijalnih turističkih lokaliteta. Potencijalni lokaliteti ravnomjerno su raspoređeni u svim istarskim gradovima i općinama.

Potencijalni memorijalni turistički lokaliteti povezani s tragičnim događajima u Prvom svjetskom ratu najvećim su dijelom smješteni u gradu Puli, koja je u tom razdoblju glavna austrougarska ratna luka i vojna baza gdje su brojni ratni brodovi bili usidreni do samoga kraja rata. Najvažniji lokalitet u Puli je Mornaričko groblje na kojem je sahranjeno oko 150000 vojnika i civila tijekom gotovo stotinu godina (1862. - 1960.), uključujući austrougarske admirale. Mornaričko groblje posljednje je počivalište civilnih i vojnih žrtava Prvoga i Drugoga svjetskog rata, a na njemu su kao najmarkantnije točke spomenik austrijskom i hrvatskom admiralu Janku Vukoviću Podkapelskom te grob Nazarija Saura, talijanskoga domoljuba i pomorca rodom iz Austrije kojeg su u Puli pogubile austrijske vlasti. ${ }^{5}$ Drugi lokaliteti u Puli povezani s Prvim svjetskim ratom jesu spomenik austro-ugarskom bojnom brodu Viribus Unitis, potopljenu diverzijom, a čiji su dijelovi uklonjeni s morskoga dna pulske luke i prebačeni u talijanske muzeje te spomenik pobunjenim austro-ugarskim mornarima u obližnjem parku. Oba se spomenika nalaze u središnjem, obalnom dijelu pulske luke. Austro-ugarske tvrđa-

\footnotetext{
5 Posmrtni ostaci Nazarija Saura (1880. - 1916.) premješteni su iz Pule u Veneciju nakon Drugoga svjetskog rata, a grob mu je sada prazan, no redovito posjećen i ukrašen cvijećem.
} 
of the defence system of Pula's naval and military base, could not be established as potential memorial tourism sites, rather as sites of heritage tourism, as suggested by Mrđen (2017). Outside of Pula, the most significant memorial tourism sites are the shipwreck of the Baron Gautsch passenger liner near Rovinj (Cherin, 1993), the Cesare Rossarol warship shipwreck near the Ližnjan Municipality, and local cemeteries (Tab. 2).

Potential memorial tourism sites associated with the tragic events of the Interwar period are much less common than those of the two World Wars. Nevertheless, this period was one of great social and political turmoil in Istria, which was then under the brutal rule of fascist Italy. The brutality of the regime provoked resistance due to the systematic suppression of Croatian and Slovenian national identities and human rights and consequently, this resistance resulted in bloody and cruel reprisals enacted by the Italian state authorities and fascist paramilitary troops (Drndić, 1978; Dukovski 2001; 2011a; Mikolić, 2003; Scotti, 2008). Potential memorial tourism sites are those where political persecution, and the execution of individuals and armed and similar conflicts occurred. The best known sites are the commemorative sites in Pula, the locations of armed conflicts related to the coal miners' uprising known as the "Labin Republic" (the town Labin and its surroundings), and the peasant rebellion in Marčana Municipality, known as the Proštinska buna ${ }^{6}$. In the collective memory of the population, the most significant are those places where the Istrian patriot and antifascist Vladimir Gortan (1904-1929) was executed (Gortan Cove in Pula's central, coastal tourist and recreational zone) and buried (the settlement Podberam-part of the town of Pazin). Other important memorial tourism sites from the Interwar period are local cemeteries, museums, temporary and permanent exhibitions, the Historical and Maritime Museum of Istria (Pula), the castle in Pazin, and buildings where local police and military prisons operated (Tab. 2).

Potential memorial tourism sites associated with the tragic events of WWII and the immedi-

6 The most important site of this rebellion against fascist oppression is the village Šegotići. Paramilitary fascist troops burned it to the ground in response to the peasant uprising in the Marčana Municipality. ve kao dio obrambenoga sustava pomorske i vojne baze Pula ne mogu se uvrstiti kao potencijalni memorijalni turistički lokaliteti, već kao mjesta baštinskoga turizma, kako je to predložila Mrđen (2017). Izvan Pule najznačajniji su memorijalni turistički lokaliteti mjesta brodoloma putničkoga broda Baron Gautsch na morskom dnu u blizini grada Rovinja (Cherin, 1993) i ratnoga broda Cesare Rossarol na morskom dnu u akvatoriju općine Ližnjan te mjesna groblja (tab. 2).

Potencijalni lokaliteti memorijalnoga turizma koji su povezani s tragičnim događajima u međuratnom razdoblju mnogo su rjeđi nego oni iz dvaju svjetskih ratova. Ipak, to je razdoblje obilježeno velikim društvenim i političkim previranjima u Istri, tada pod talijanskom vlašću, koju je karakterizirao brutalan i opresivan fašistički režim. Brutalnost režima izazvao je otpor ugrožavanju hrvatskoga i slovenskoga nacionalnog identiteta i ljudskih prava, a posljedično, krvave i okrutne represalije talijanskih državnih vlasti i fašističkih paravojnih trupa (Drndić, 1978; Dukovski 2001; 2011a; Mikolić, 2003; Scotti, 2008). Potencijalni su lokaliteti memorijalnoga turizma oni gdje su se dogodili progoni stanovništva, pogubljenja pojedinaca, oružani i slični sukobi. Najpoznatiji lokaliteti mjesta su komemoracija žrtvama radničkih prosvjeda u središtu Pule, mjesta oružanih sukoba povezanih s ustankom rudara ugljena poznatim kao Labinska republika (grad Labin i okolica) i pobunom seljaka u općini Marčana poznatom kao Proštinska buna. ${ }^{6}$ U kolektivnom sjećanju stanovništva najznačajnija su ona mjesta na kojima je istarski domoljub i antifašist Vladimir Gortan (1904. - 1929.) pogubljen (Gortanova uvala u središnjoj, obalnoj turističkoj i rekreacijskoj zoni grada Pule) i sahranjen (naselje Podberam, grad Pazin). Druga važna mjesta memorijalnoga turizma iz međuratnoga razdoblja jesu lokalna groblja, muzeji, privremene i stalne izložbe, Povijesni i pomorski muzej Istre (Pula), Kaštel (Pazin) i zgrade u kojima su djelovali lokalni policijski i vojni zatvori (tab. 2).

Potencijalni lokaliteti memorijalnoga turizma povezani s tragičnim događajima u Drugom svjet-

\footnotetext{
6 Najvažnije mjesto ove pobune protiv fašističkoga ugnjetavanja jest selo Šegotići. Paravojne fašističke postrojbe spalile su ovo selo do temelja kao odgovor na seljački otpor i nemire u općini Marčana.
}

The potential of memorial tourism development in Istria (Croatia)

Potencijali razvoja memorijalnog turizma u Istri (Hrvatska) 
GEOGRAFSKI

GLASNIK

$82 / 2,107-129(2020$.)
Tab. 2 The potential memorial tourism sites by historical period of the $20^{\text {th }}$ century*

Tab. 2. Potencijalni lokaliteti memorijalnoga turizma prema povijesnom razdoblju 20. stoljeća*

\begin{tabular}{|c|c|c|c|}
\hline \multirow[b]{2}{*}{$\begin{array}{l}\text { Type of memorial tourism sites } \\
\text { /Tip lokacija memorijalnog } \\
\text { turizma }\end{array}$} & \multicolumn{3}{|c|}{ Potential sites by period / Potencijalne lokacije prema razdoblju } \\
\hline & $\begin{array}{l}\text { World War I } \\
\text { / Prvi svjetski rat }\end{array}$ & $\begin{array}{l}\text { Interwar period } \\
\text { /Međuratno razdoblje }\end{array}$ & $\begin{array}{l}\text { World War II and the } \\
\text { immediate aftermath } \\
\text { / Drugi svjetski rat i } \\
\text { neposredno poraće }\end{array}$ \\
\hline $\begin{array}{l}\text { Memorial exhibitions and } \\
\text { museums } \\
\text { / Memorijalne zbirke i } \\
\text { muzeji }\end{array}$ & \multicolumn{3}{|c|}{$\begin{array}{l}\text { Local museums, The Historical and Maritime Museum of Istria (Pula) } \\
\text { / Lokalni muzeji, Povijesni i pomorski muzej Istre (Pula) }\end{array}$} \\
\hline $\begin{array}{l}\text { Places of internment: } \\
\text { Prisons and camps } \\
\text { / Zatočeništvo: } \\
\text { zatvori i logori }\end{array}$ & \multicolumn{3}{|c|}{$\begin{array}{l}\text { Castle (Pazin), Local police and military prisons (different locations) } \\
\text { / Kaštel (Pazin), Lokalni policijski i vojni zatvori (različite lokacije) }\end{array}$} \\
\hline $\begin{array}{l}\text { Cemeteries } \\
\text { / Groblja }\end{array}$ & \multicolumn{2}{|c|}{$\begin{array}{c}\text { The Navy cemetery (Pula), } \\
\text { Local cemeteries (different locations) } \\
\text { / Mornaričko groblje (Pula), } \\
\text { lokalna groblja (različite lokacije) }\end{array}$} & $\begin{array}{c}\text { The Navy Cemetery (Pula), } \\
\text { Cemetery (Pazin), } \\
\text { Local Cemeteries } \\
\text { / Mornaričko groblje (Pula), } \\
\text { Groblje (Pazin), } \\
\text { lokalna groblja }\end{array}$ \\
\hline $\begin{array}{l}\text { Place of death or burial of } \\
\text { historical personage } \\
\text { / Mjesto pokopa ili stradavanja } \\
\text { znamenitih povijesnih osoba }\end{array}$ & $\begin{array}{l}\text { Nazario Sauro, } \\
\text { (The Navy cemetery Pula } \\
\text { / Mornaričko groblje u Puli) }\end{array}$ & $\begin{array}{c}\text { Vladimir Gortan, } \\
\text { Gortan's Cove (Pula), } \\
\text { Beram and Podberam (Pazin) } \\
\text { / Gortanova uvala (Pula), } \\
\text { Beram i Podberam (Pazin) }\end{array}$ & $\begin{array}{c}\text { Joakim Rakovac (Poreč), } \\
\text { Ruža Petrović } \\
\text { (Svetvinčenat and Pula), } \\
\text { Jože Šuran (Višnjan), } \\
\text { Pino Budicin (Rovinj), } \\
\text { Aldo Negri (Vrsar), } \\
\text { Olga Ban (Pazin), } \\
\text { Marija Medica, } \\
\text { Lina Zacchigna (Umag) }\end{array}$ \\
\hline $\begin{array}{l}\text { Battle and armed conflicts } \\
\text { / Bitke i oružani sukobi }\end{array}$ & $\begin{array}{l}\text { Naval Port of Pula } \\
\text { / Ratna luka (Pula) }\end{array}$ & $\begin{array}{c}\text { Town Labin, } \\
\text { Šegotići (Marčana), } \\
\text { Gortanov Brijeg (Pazin) } \\
\text { / Grad Labin, } \\
\text { Šegotići (Marčana), } \\
\text { Gortanov Brijeg (Pazin) }\end{array}$ & $\begin{array}{c}\text { Eastern Istria / Istočna Istra } \\
\text { (Raša and Labin), } \\
\text { Tićan (Višnjan), } \\
\text { Jadreški (Ližnjan), } \\
\text { Limska draga } \\
\text { (Rovinj and Vrsar), } \\
\text { Ćićarija (Lanišće and Buzet), } \\
\text { Kućibreg (Buje) }\end{array}$ \\
\hline $\begin{array}{c}\text { Mass casualties of populations } \\
\text { / Masovno stradavanje } \\
\text { stanovništva }\end{array}$ & $\begin{array}{l}\text { Seabed near to town of Rovinj } \\
\text { / Morsko dno kod Rovinja }\end{array}$ & $\begin{array}{l}\text { Town Labin and Pula, } \\
\text { Municipality Marčana } \\
\text { / Gradovi Labin i Pula, } \\
\text { Općina Marčana }\end{array}$ & $\begin{array}{c}\text { Šajini (Barban), } \\
\text { Bokordići (Svetvinčenat), } \\
\text { Kresini (Žminj), } \\
\text { Zabrežani (Pazin), } \\
\text { Gajana (Vodnjan), } \\
\text { Veli Vrh, Vargarola, } \\
\text { Medulinska street (Pula), } \\
\text { Karst and bauxite pits } \\
\text { (different locations) } \\
\text { / Krške i boksite jame } \\
\text { (različite lokacije) }\end{array}$ \\
\hline $\begin{array}{l}\text { Podvodne lokacije } \\
\text { / Seabed places }\end{array}$ & $\begin{array}{c}\text { Seabed near to } \\
\text { town of Rovinj, } \\
\text { Premantura (Medulin), } \\
\text { Ližnjan municipality } \\
\text { /Morsko dno } \\
\text { kod grada Rovinja, } \\
\text { Premanture (Medulin) i } \\
\text { općine Ližnjan }\end{array}$ & - & $\begin{array}{l}\text { Seabed near to } \\
\text { Plomin (Kršan) and } \\
\text { Town of Novigrad } \\
\text { / Morsko dno kod } \\
\text { Plomina (Kršan) i } \\
\text { grada Novigrada }\end{array}$ \\
\hline
\end{tabular}

* Names in the brackets are Istrian municipalities and towns / Imena u zagradama su istarske općine i gradovi 
ate post-WWII period are the most numerous and most prevalent in collective memory and the most present in the national identity of the Istrian population. According to Šuligoj (2019) and Kennel et al. (2018), these sites are dominant in the media and often the most frequently visited: official commemorative events are often organised and they are promoted by the towns' municipal and county governments and their respective offices. The active participants and promoters of such public events are local schools, cultural and historical societies, as well as antifascist and human rights associations. Nevertheless, having used the analysis on the website istria-culture.com, municipality and town websites, and local tourism boards, these commemorative events were not recognised or promoted as cultural or memorial tourism events and sites.

The most prominent memorial museums and exhibitions dedicated to the tragic events of WWII are the Historical and Maritime Museum of Istria in Pula, museums in Labin, Pazin, Poreč, Rovinj, Buzet, and the Memorial Exhibition Room in the rural settlement of Šaini (Barban Municipality). Places of internment in the WWII period, which are potential memorial tourism sites, include Pula's prison, Pazin's Castle, and local police and military prisons, distributed evenly among Istrian towns and municipalities. Apart from the Naval Cemetery in Pula, the most famous cemetery from the WWII period is found in Pazin, where numerous civilians were executed during the German occupation of Istria.

The places of death and burial sites of historical personages are deeply connected to the collective memory and national identity of the Istrian population. It is for this reason that they are mentioned by Kennel et al. (2018), Drvenkar et al. (2015), and Vukojević and Opačić (2017); such sites are marked with memorial plaques and monuments and could inform a part of the memorial tourism supply. During WWII, many battles and armed conflicts between German armed forces and antifascist combatants (partisans) occurred in Istrian territory. The most tragic armed conflicts, with the greatest number of human casualties, were the battles near the town Labin, the village Tićan (Višnjan Municipality), the Magran Forest near the vil- skom ratu i neposrednom poslijeratnom razdoblju najbrojniji su i najprisutniji u kolektivnom sjećanju i nacionalnom identitetu istarskoga stanovništva. Prema Šuligoju (2019) i Kennelu i dr. (2018) ovi su lokaliteti dominantni, pokriveni medijskim izvještajima i novinarskim člancima te su najčešće posjećeni kao službene prigodne manifestacije koje organiziraju i promoviraju gradske, općinske i županijske vlasti i njihovi uredi. Aktivni promotori i sudionici takvih javnih događaja su lokalne škole, kulturna i povijesna društva, kao i antifašističke udruge te udruge za ljudska prava. Ipak, upotre $\neg$ bljavajući analizu mrežnih stranica Istarska kultura (istria-culture.com) i mrežnih stranica općina i gradova te lokalnih turističkih zajednica, utvrđeno je da se ti komemorativni događaji ne prepoznaju i promoviraju kao kulturni ili memorijalni turistički događaji ili lokaliteti.

Najistaknutiji memorijalni muzeji i izložbe o tragičnim događajima u Drugom svjetskom ratu su Povijesni i pomorski muzej Istre u Puli, muzeji u gradovima Labinu, Pazinu, Poreču, Rovinju, Buzetu te spomen-soba u selu Šajini (općina Barban). Mjesta zatočeništva iz Drugoga svjetskog rata kao tip lokaliteta memorijalnoga turizma su Pulski zatvor, pazinski Kaštel te lokalni policijski i vojni zatvori, ravnomjerno raspoređeni po istarskim gradovima i općinama. Osim Mornaričkoga groblja u Puli, najpoznatije je groblje iz Drugoga svjetskog rata ono u gradu Pazinu, gdje su tijekom njemačke okupacije Istre pogubljeni brojni civili.

Mjesta pogibije ili ukopa povijesnih osoba duboko su povezana s kolektivnim pamćenjem i nacionalnim identitetom istarskoga stanovništva. Zato su, kao što napominju Kennel i dr. (2018), Drvenkar i dr. (2015) te Vukojević i Opačić (2017), takvi lokaliteti označeni spomen-pločama i spomenicima te bi mogli postati dio ponude memorijalnoga turizma. Tijekom Drugoga svjetskog rata na prostoru Istre dogodile su se brojne bitke i drugi oružani sukobi između njemačkih oružanih snaga i antifašističkih boraca (partizanske vojske). Najtragičniji oružani sukobi po broju ljudskih žrtava bile su bitke u blizini grada Labina, sela Tićan (općina Višnjan), šume Magran u blizini sela Jadreški (općina Ližnjan), Limska draga
The potential of memorial tourism development in Istria (Croatia)

Potencijali razvoja memorijalnog turizma u Istri (Hrvatska) 
lage Jadreški (Ližnjan Municipality), Limska draga (between the town Rovinj and Vrsar Municipality), the Ćićarija Plateau (Lanišće Municipality and town Buzet), the village Kućibreg (the town Buje), and so on. Places where mass casualties among the population occurred during WWII certainly rank among the most tragic sites for memorial tourism due to the large-scale atrocities committed by German armed forces and fascist paramilitary forces against women, children, and the elderly. Such locations are found all over Istria and remain in the collective memory of the locals. For this reason, these places of mass casualties are commemorated regularly. The most notorious places of such mass executions of civilians are the villages Šaini (Barban Municipality), Bokordići (Svetvinčenat $\mathrm{Mu}-$ nicipality), Gajana (Vodnjan), Zabrežani (Pazin), Kresini (Žminj Municipality), the Ćićarija Plateau settlements (Lanišće Municipality and Buzet) and Pula city districts, including an explosion in Fort Valmarin (Fort Bradamante) killing 19 people (September 1943) and the tragedy after WWII (August 1946) in Vargarola Cove (Dukovski, 2011a; 2011b) when abandoned sea mines exploded, killing 63 people (Tab. 2).

Using the results of website analysis, fieldwork, participant observation, mapping and photo documentation, the potential memorial tourism sites in Istria connected with the tragic events of WWII have been classified into two main groups. Classification criteria are media coverage and the participation of local, regional (Istria County) and state authorities in commemorative events. The first group, as considered by Šuligoj (2019) and Kennel et al. (2018), consists of sites connected with armed resistance by Slovenian, Croatian, and Italian antifascist movements against German occupying forces and fascist paramilitary troops. This group also includes sites connected with persecution, torture, atrocities, and execution of individuals and the civil population committed by German regular armed forces and fascist paramilitary forces during the last two years of WWII (September 1943-May 1945). These potential memorial tourism sites are well covered by media reports ${ }^{7}$ and commemorat-

\footnotetext{
7 In his paper, Suligoj (2019) analysed three leading regional newspapers (printed and electronic versions) from the Croatian and Slovenian parts of Istria: Primorske novice; Glas Istre; and La voce del popolo. Besides
}

(između grada Rovinja i općine Vrsar), na Ćićariji (općina Lanišće i grad Buzet), kraj sela Kućibreg (grad Buje) te drugi lokaliteti. Mjesta masovnoga stradavanja stanovništva u Drugom svjetskom ratu najtragičniji su potencijalni lokaliteti memorijalnoga turizma zbog težine i masovnosti zločina koje su počinile njemačke oružane snage i fašistička paramilicija nad ženama, djecom i starijim osobama. Takve lokacije mogu se pronaći diljem Istre i još uvijek su u kolektivnom sjećanju lokalnoga stanovništva. Stoga se mjesta masovnoga stradavanja stanovništva redovito službeno komemoriraju. Najzloglasnija su mjesta takvih masovnih pogubljenja civila sela Šajini (općina Barban), Bokordići (općina Svetvinčenat), Gajana (grad Vodnjan), Zabrežani (grad Pazin), Kresini (općina Žminj), naselja na Ćićariji (općina Lanišće i grad Buzet) te gradske četvrti Pule, uključujući eksploziju u utvrdi Valmarin (bivši Fort Bradamante) prilikom koje je smrtno stradalo 19 ljudi te tragediju nakon Drugoga svjetskog rata (kolovoz 1946.) u uvali Vargarola (Dukovski, 2011a; 2011b), kad su eksplodirale napuštene morske mine, pri čemu su poginule 63 osobe (tab. 2).

Upotrebom rezultata analize mrežnih stranica, terenskih istraživanja, sudioničkoga promatranja, kartiranja i fotodokumentiranja potencijalni lokaliteti memorijalnoga turizma u Istri povezani s tragičnim događajima u Drugom svjetskom ratu klasificirani su u dvije glavne skupine. Kriteriji za klasifikaciju su medijska pokrivenost i sudjelovanje lokalnih, regionalnih (Istarska županija) i državnih vlasti u komemorativnim događajima. Prvu skupinu koju su razmatrali Šuligoj (2019) te Kennel i dr. (2018) čine lokaliteti povezani s oružanim otporom slovenskoga, hrvatskoga i talijanskoga antifašističkog pokreta njemačkim okupacijskim snagama i fašističkim paravojnim postrojbama. Ova skupina uključuje i lokalitete povezane s progonima, mučenjima, zločinima te pogubljenjima pojedinaca i civilnoga stanovništva koje su počinile njemačke regularne oružane snage i fašistička paramilicija tijekom posljednje dvije godine Drugoga svjetskog rata (rujan 1943.- svibanj 1945.). Ti potencijalni memorijalni turistički lokaliteti dobro su praćeni u medijskim izvještajima ${ }^{7}$ i svake se

\footnotetext{
7 Suligoj (2019.) je u svom radu analizirao tri vodeće regionalne dnevne novine (tiskane i elektroničke verzije) iz hrvatskoga i slovenskoga dijela Istre: Primorske novice, Glas Istre i La voce del popolo. Osim njih,
} 
ed regularly every year by local and regional authorities, societies, and associations. The sites are well marked and connected by access roads with signposts, monuments, memorial plaques, and other symbols ${ }^{8}$. The second group consists of sites of karst and bauxite pits throughout Istrian territory where individual and mass executions occurred, perpetrated mostly by antifascist rebels during the mass spontaneous uprisings in September and October 1943 (Dukovski, 2001; Mikolić, 2003; Giron, 2004; Scotti, 2008; Pirjevec, 2009; Radošević, 2009) ${ }^{9}$. These potential memorial tourism sites are neither covered by media reports nor commemorated by local and regional authorities, although they are visited and commemorated regularly on a yearly basis by groups and individuals from abroad, mostly from Italy, who are the descendants of the victims or those who wish to pay their respects (Facchinetti, 2019). During fieldwork and participant observation, what was discovered was that karst and bauxite pits as potential memorial tourism sites are located in inaccessible and impassable terrain without signposts or arranged and marked paths. Furthermore, many of these karst and bauxite pits are overgrown with dense vegetation and contaminated with municipal waste (Rnjak et al., 2017; Novak, 2020) ${ }^{10}$.

Numerous and various sites suitable for memorial tourism in Istria with very good transport infrastructure (Njegač et al., 2010) provide opportunities to introduce innovative tourist experiences, expanding the area's generous tourism supply in a new direction. It is not a matter of the existing

these, others, mostly news websites from Istria, have published news about these commemorations.

8 One among numerous examples is the Battle of Kućibreg anniversary $\left(3^{\text {rd }} / 4^{\text {th }}\right.$ November 1944$)$ near the Slovenian-Croatian state border which is organised and promoted by Slovenian and Croatian local and regional authorities as well as antifascist associations from Italy, Slovenia, and Croatia (Grad Buje, 2019).

9 According to historians and other researchers, the corpses of the executed civilians, fascist officials, and their sympathisers were thrown into karst and bauxite pits as well as soldiers from both sides who were killed in the fighting during last two years of WWII (Dukovski, 2001; Scotti, 2008; Pirjevec, 2009; Radošević, 2009).

10 During fieldwork, the karst pits in Trlji, Palion, Trogrlica, Pucići, Gospetova jama, Šurani, the Semić Abyss, and the bauxite pits of Bakšoti and Gračišće were visited, photographed and mapped. The remains of plastic floral decorations, religious relics, and national flags placed by visitors can be seen at Gospetova jama (Sveta Nedelja Municipality) and Šranska jama (Tinjan Municipality). godine redovito obilježavaju u organizaciji lokalnih i regionalnih vlasti, društava i udruga. Lokaliteti su precizno označeni i povezani pristupnim cestama $s$ putokazima, spomenicima, spomen-pločama i drugim simbolima. ${ }^{8}$ Drugu skupinu čine lokaliteti krških i boksitnih jama smješteni u svim dijelovima Istre gdje su se dogodila pojedinačna i masovna pogubljenja, najvećim dijelom počinjena od antifašističkih ustanika tijekom masovnoga, spontanoga i neorganiziranoga ustanka u rujnu i listopadu 1943. godine (Dukovski, 2001; Mikolić, 2003; Giron, 2004; Scotti, 2008; Pirjevec, 2009; Radošević, 2009). ${ }^{9}$ Ti potencijalni lokaliteti memorijalnoga turizma nisu obuhvaćeni medijskim izvještajima regionalnih dnevnih novina niti ih komemorira lokalna i regionalna vlast u Istri premda ih svake godine posjećuju i redovno obilježavaju grupe i pojedinci iz inozemstva, uglavnom iz Italije, a koji su potomci ili štovatelji žrtava (Facchinetti, 2019). Tijekom terenskoga istraživanja i sudioničkoga promatranja utvrđeno je da su krške i boksitne jame kao potencijalni lokaliteti memorijalnoga turizma na nepristupačnom i neprohodnom terenu bez putokaza ili uređenih i označenih staza. Danas je većina tih krških i boksitnih jama obrasla gustom vegetacijom i onečišćena komunalnim otpadom (Rnjak i dr., 2017; Novak, 2020). ${ }^{10}$

Mnogobrojni i raznovrsni lokaliteti pogodni za memorijalni turizam, vrlo dobra mreža prometnica (Njegač i dr., 2010) te brojnost i raspored smještajnih kapaciteta u Istri pružaju mogućnost uvođenja inovativnih turističkih doživljaja obogaćujući turističku ponudu koja se do sada nije koristila. Bez obzira na postojeće kulturne i/

i drugi, uglavnom internetski informativni portali iz Istre, također su objavili vijesti o tim komemoracijama.

8 Jedan od brojnih primjera je proslava godišnjice bitke kod Kućibrega (3./4. studenoga 1944.) blizu slovensko-hrvatske državne granice koju organiziraju i promoviraju slovenske i hrvatske lokalne i regionalne vlasti, kao i antifašistička udruženja iz Italije, Slovenije i Hrvatske (Grad Buje, 2019).

9 Prema istraživanjima povjesničara i drugih istraživača tijela pogubljenih civila, dužnosnika fašističkoga režima te njihovih simpatizera bačena su u krške i boksitne jame isto kao i tijela vojnika obiju sukobljenih strana koji su ubijeni u borbama tijekom posljednje dvije godine Drugoga svjetskog rata (Dukovski, 2001; Scotti, 2008; Pirjevec, 2009; Radošević, 2009).

10 Tijekom terenskih istraživanja posjećene su, kartirane i fotografirane krške jame Trlji, Palijon, Trogrlice, Pucići, Gospetova jama, Šuranska jama, Semićki ponor i boksitne jame Bakšoti i Gračišće. Ostatci plastičnih cvjetnih ukrasa, vjerskih relikvija i državnih zastava koje su postavili poštovatelji mogu se vidjeti na rubu Gospetove jame (općina Sveta Nedelja) i Šuranske jame (općina Tinjan).
The potential of memorial tourism development in Istria (Croatia)

Potencijali razvoja memorijalnog turizma u Istri (Hrvatska) 
GEOGRAFSKI

GLASNIK

82/2,107-129 (2020.) cultural and/or heritage routes in Istria as some the researchers have considered and suggested (Gržinić and Vodeb, 2015; Afrić Rakitovac and Urošević, 2017; Afrić Rakitovac et al., 2019), rather that memorial tourism routes can be developed independently, thus complementing and improving the entire tourism supply. Such examples of good practice of including memorial tourist routes in the tourism supply are the Pot mira (The Path of Peace) in the Slovenian and Italian part of the Soča (Isonzo) Valley tourism region (Šuligoj, 2017a; Kennell et al., 2018; Foundations Walk of peace in Isonzo valley, 2018); the Trail of the heroes of the Slovak $\mathrm{Na}$ tional Uprising in 1944 in Slovakia (Horodnikova and Derco, 2015), and the Path of peace in the $\mathrm{Au}^{-}$ tonomous Province of Trentino in northern Italy (Irimiás, 2014).

The analysis of historical sources, papers, books and other publications has shown that the numerous locations suitable for memorial tourism sites and/or as points (stations) of thematic routes of memorial tourism are primarily dedicated to the tragic events of the first half of the $20^{\text {th }}$ century in Istria. The same results, derived from data collected through fieldwork, participant observation, mapping and photographic documentation, indicate a large number of such potential sites throughout Istria as well. These results were used to compile and propose a list of potential memorial tourism sites and, according to the researcher, the most significant points for memorial tourism thematic routes were selected (Fig. 1) ${ }^{11}$.

As mentioned earlier, in the final phase of this research, thematic routes of memorial tourism in Istria were proposed. In accordance with the large number of potential sites of memorial tourism in all towns and municipalities, as well as the proposed major points in Istria, six thematic routes of memorial tourism can be identified: the Pula route; the Route of the resistance to the suppression of national identity 1918-1943; the Battles route 1943-1945; the Route of mass population casualties of 1943-1945; the Route of karst and bauxite pits 1943-1945; and the Submarine tours of shipwrecks from WWI and WWII (Tab. 3).

11 Every town and almost every larger rural settlement in Istria has raised some type of monument dedicated to the memory of tragic events. ili baštinske rute u Istri, kao što su neki istraživači razmatrali i sugerirali (Gržinić i Vodeb, 2015; Afrić Rakitovac i Urošević, 2017; Afrić Rakitovac i dr., 2019), memorijalne turističke rute mogle bi se samostalno razvijati i nadopunjavati te poboljšati cjelokupnu ponudu turizma. Primjeri dobre prakse uključivanja memorijalnih turističkih ruta u ukupnu ponudu su Put mira koja se pruža u slovenskom i talijanskom dijelu turističke regije doline Soče (Isonzo) (Šuligoj, 2017a; Kennell i dr., 2018; Foundations Walk of peace in Isonzo valley, 2018), Staza heroja Slovačkoga nacionalnog ustanka 1944. u Slovačkoj (Horodnikova i Derco, 2015) i Put mira u autonomnoj provinciji Trentino, sjeverna Italija (Irimiás, 2014).

Analiza povijesnih izvora, znanstvenih radova i knjiga te drugih publikacija o tragičnim događajima prve polovice 20. stoljeća u Istri upozorila je na veliki broj potencijalnih lokaliteta koji su pogodni za memorijalni turizam pojedinačno $\mathrm{i} / \mathrm{ili}$ kao punktovi memorijalnih turističkih ruta. Rezultati proistekli iz podataka prikupljenih terenskim radom, sudioničkim promatranjem, kartiranjem i fotografskim dokumentiranjem također su potvrdili velik broj takvih potencijalnih lokaliteta diljem Istre. Ovi su rezultati poslužili za sastavljanje i predlaganje popisa potencijalnih lokacija memorijalnoga turizma, a odlukom autora odabrani su najznačajniji punktovi tematskih ruta memorijalnoga turizma (sl. 1). ${ }^{11}$

Kao što je prethodno spomenuto, u završnoj fazi ovoga istraživanja predlažu se tematske rute memorijalnoga turizma u Istri. U skladu s utvrđenim brojnim potencijalnim lokalitetima memorijalnoga turizma u svim gradovima i općinama, kao i predloženim glavnim punktovima (sl. 1), u Istri se predlaže šest tematskih ruta memorijalnoga turizma: Pulska ruta, Put otpora suzbijanju nacionalnoga identiteta 1918. - 1943., Ruta bitaka 1943. - 1945., Ruta masovnoga stradavanja stanovništva 1943. - 1945., Ruta krških i boksitnih jama 1943. - 1945. i Podmorski obilasci potopljenih brodova iz svjetskih ratova (tab. 3).

\footnotetext{
11 Svaki grad i gotovo svako veće ruralno naselje u Istri postavilo je neki tip spomenika posvećena sjećanju na tragične događaje.
} 


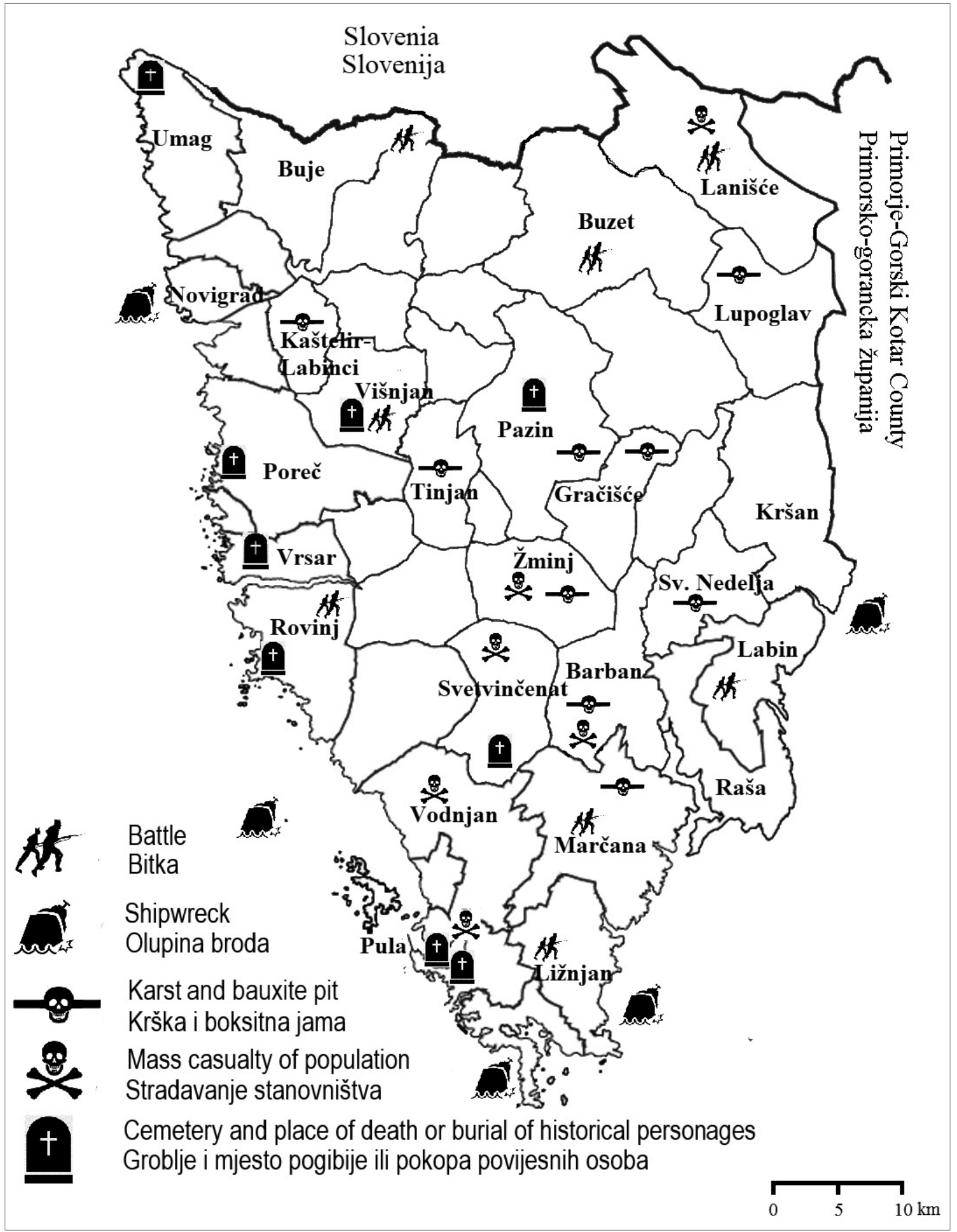

The potential of memorial tourism development in Istria (Croatia)

Potencijali razvoja memorijalnog turizma u Istri

(Hrvatska)

Fig. 1 The most significant points for memorial tourism thematic routes in Istria

SI. 1. Najznačajniji punktovi na tematskim rutama memorijalnoga turizma u Istri 
Tab. 3 Memorial tourism thematic routes in Istria

Tab. 3. Tematske rute memorijalnoga turizma u Istri

\begin{tabular}{|c|c|c|}
\hline $\begin{array}{l}\text { Thematic route } \\
\text { / Tematska ruta }\end{array}$ & $\begin{array}{l}\text { Historical period } \\
\text { / Povijesno razdoblje }\end{array}$ & $\begin{array}{l}\text { Town/Municipality } \\
\text { Grad/Općina }\end{array}$ \\
\hline $\begin{array}{l}\text { Pula route } \\
\text { / Pulska ruta }\end{array}$ & $\begin{array}{l}\text { World War I / Prvi svjetski rat } \\
\text { Interwar period / Međuratni period } \\
\text { World War II and the immediate post-war period } \\
\text { / Drugi svjetski rat i neposredno poraće }\end{array}$ & Pula \\
\hline $\begin{array}{c}\text { Route of the resistance to suppression of } \\
\text { national identity } 1918-1943 \\
\text { / Ruta otpora gušenju nacionalnog } \\
\text { identiteta 1918. - 1943. }\end{array}$ & $\begin{array}{l}\text { Interwar period } \\
\text { / Međuratni period }\end{array}$ & $\begin{array}{l}\text { Labin } \\
\text { Marčana } \\
\text { Pazin } \\
\text { Pula }\end{array}$ \\
\hline $\begin{array}{l}\text { Battles' Route } 1943-1945 \\
\text { / Ruta bitaka 1943. }-1945 .\end{array}$ & $\begin{array}{l}\text { World War II } \\
\text { / Drugi svjetski rat }\end{array}$ & $\begin{array}{c}\text { Buje } \\
\text { Buzet } \\
\text { Labin } \\
\text { Lanišće } \\
\text { Ližnjan } \\
\text { Pula } \\
\text { Raša } \\
\text { Rovinj } \\
\text { Višnjan } \\
\text { Vrsar }\end{array}$ \\
\hline \begin{tabular}{|} 
Route of mass casualties of population \\
$1943-1945$ \\
/ Ruta masovnog stradavanja stanovništva \\
1943. -1945.
\end{tabular} & $\begin{array}{l}\text { World War II and the immediate post-war period } \\
\text { / Drugi svjetski rat i neposredno poraće }\end{array}$ & $\begin{array}{c}\text { Barban } \\
\text { Buzet } \\
\text { Lanišće } \\
\text { Lupoglav } \\
\text { Pazin } \\
\text { Pula } \\
\text { Svetvinčenat } \\
\text { Vodnjan } \\
\text { Žminj }\end{array}$ \\
\hline $\begin{array}{l}\text { Route of karst and bauxite pits } \\
\qquad 1943-1945 \\
\text { / Ruta krških i boksitnih jama } \\
\text { 1943. - 1945. }\end{array}$ & $\begin{array}{l}\text { World War II and the immediate post-war period } \\
\text { / Drugi svjetski rat i neposredno poraće }\end{array}$ & $\begin{array}{c}\text { Barban } \\
\text { Gračišce } \\
\text { Kaštelir-Labinci } \\
\text { Lupoglav } \\
\text { Marčana } \\
\text { Pazin } \\
\text { Sveta Nedjelja } \\
\text { Tinjan } \\
\text { Žminj } \\
\end{array}$ \\
\hline $\begin{array}{c}\text { Submarine tours of shipwrecks } \\
\text { from world wars } \\
\text { / Podmorski obilasci potopljenih brodova } \\
\text { iz svjetskih ratova }\end{array}$ & $\begin{array}{l}\text { World War II and the immediate post-war period } \\
\text { / Drugi svjetski rat i neposredno poraće }\end{array}$ & $\begin{array}{l}\text { Kršan } \\
\text { Ližnjan } \\
\text { Medulin } \\
\text { Novigrad } \\
\text { Rovinj }\end{array}$ \\
\hline
\end{tabular}


Pula route. This thematic route of memorial tourism should encompass and unite all three historical periods in the first half of the $20^{\text {th }}$ century. The most important points on this route are the Naval Cemetery, Gortan and Vargarola Cove, the downtown area and central part of Pula's port, the Monte Ghiro Town Cemetery, Medulin Street, the town quarter Veli vrh, and the Valmarin Fortress (formerly the Bradamante Fortress). The advantages of this route are the fact that all its points are connected by a network of city buses and public roads and that tourist accommodation is located nearby. There is also the advantage that, besides natural and anthropogenic tourist attractions, potential memorial tourists can also use the other urban content Pula has to offer: this makes visits to these localities much easier. A potential disadvantage of this route is that its content and points are intertwined with the content of other specific forms of tourism and recreation in Pula: such content represents leisure and entertainment as a means to spend one's free time.

Route of the resistance to the suppression of national identity 1918-1943. The most important points of this thematic route of memorial tourism are in the city Pula, where, in the first years after WWI, numerous tragic events occurred connected to the suppression of national identity. The second group of such routes is in the neighbouring Marčana Municipality and the settlements of Šegotići, Kavran, Krnica, Mutvoran and all others which are all linked to the Proštinska buna uprising. The town Labin, with localities connected to the miner's uprising of the "Labin Republic" is the third group of points along this route, and the final group of these points are two settlements of the town Pazin: Beram and Podberam. All the potential localities of this route are close to tourist accommodation, and are all connected to public roads, yet not necessarily with intercity public transport.

Battles route 1943-1945. This route connects the settlements where (or in the vicinity) great battles or armed conflict took place during the final two years of WWII. The key points of this thematic route of memorial tourism are the Magran Forest in close proximity to Jadreški settlement (Ližnjan Municipality), the town quarter Stoja in
Pulska ruta. Ova tematska ruta memorijalnoga turizma obuhvatila bi i objedinila sva tri povijesna razdoblja prve polovice 20. stoljeća. Najvažniji punktovi na ruti su Mornaričko groblje, Gortanova i uvala Vargarola, najuže gradsko središte, središnji dio pulske luke, Gradsko groblje Monte Ghiro, Medulinska ulica, četvrt Veli vrh i Fort Valmarin (bivši Fort Bradamante). Prednosti ove rute su u tome što su svi punktovi povezani mrežom javnoga gradskog autobusnog prijevoza i javnim cestovnim prometnicama te što se u neposrednoj blizini nalaze turistički smještajni kapaciteti. Također je prednost to što se uz prirodne i antropogene turističke atrakcije potencijalni memorijalni turisti mogu koristiti drugim urbanim pogodnostima Pule koje olakšavaju posjet lokalitetima. Mogući nedostatak ove rute je u tome što su njezini sadržaji i punktovi isprepleteni sa sadržajima drugih posebnih oblika turizma i rekreacije u Puli, a koji po svojoj ponudi spadaju u ležernije i zabavnije načine provođenja slobodnoga vremena.

Ruta otpora suzbijanju nacionalnoga identiteta 1918. - 1943. Najvažniji punktovi ove tematske rute memorijalnoga turizma nalaze se u gradu Puli, u kojoj su se u prvim godinama nakon Prvoga svjetskog rata zbili brojni tragični događaji povezani s otporom Hrvata i Slovenaca suzbijanju svoga nacionalnoga identiteta. Druga skupina punktova ove rute je Puli susjedna općina Marčana, odnosno njezina naselja Marčana, Šegotići, Kavran, Krnica, Mutvoran i druga koja su povezana s događajima iz Proštinske bune. Grad Labin s lokalitetima povezanim s ustankom rudara Labinska republika treća je skupina punktova ove rute, a posljednja skupina punktova su naselja grada Pazina: Beram i Podberam. Svi potencijalni lokaliteti na ovoj ruti u blizini su turističkih smještajnih kapaciteta, povezani su međusobno javnim cestama, ali ne nužno i javnim međugradskim autobusnim prijevozom.

Ruta bitaka 1943. - 1945. Ruta spaja naselja na čijem su se području ili u neposrednoj blizini vodile bitke i drugi oružani sukobi tijekom zadnjih dviju godina Drugoga svjetskog rat. Ključni punktovi ove rute memorijalnoga turizma su šuma Magran u neposrednoj blizini naselja Jadreški (općina Ližnjan), gradska četvrt Stoja u Puli, Limska draga
The potential of memorial tourism development in Istria (Croatia)

Potencijali razvoja memorijalnog turizma u Istri (Hrvatska) 
Pula, Limska draga between Rovinj and the Vrsar Municipality, the village Tićan (Višnjan Municipality), the village Kućibreg in upper Bujština (the Town of Buje), the Cićarija Plateau settlements in the Lanišće Municipality and Buzet, as well as Labin and the Raša Municipality. The points along this route are well connected with public roads, and in part are connected by public intercity buses. One special advantage of this route is that it can be thematically linked in its northern and northeastern parts with potential memorial tourism routes in Slovenia and Primorsko-Goranska County.

Route of mass population casualties of 19431945. Points are located along these memorial tourism routes where official commemorations in memory of the fallen civil population take place; these events do not, however, have the characteristics of memorial tourism at the time of writing. This route connects parts of Pula with the village Gajana in the area of Vodnjan, Šajini in Barban Municipality, Bokordići in Svetvinčenat Municipality, Kresini in Žminj Municipality, Zabrežani in the wider surroundings of Pazin, as well as villages on the Ćićarija Plateau, those surrounding Buzet, and in the municipalities of Lanišce and Lupoglav. In the area of these towns and municipalities there are other, similar points which fit in with the route due to their content. Similarly, this memorial tourism route, as in the aforementioned case, can be thematically linked with potential routes which could include the village Lipa (Matulji Municipality) in neighbouring Primorsko-Goranska County.

Route of karst and bauxite pits 1943-1945. These encompass the karst and bauxite pits which undoubtedly signify execution sites during WWII (Dukovski, 2001; Mikolić, 2003; Giron, 2004; Scotti, 2008; Pirjevec, 2009; Radošević, 2009). This the matic route of memorial tourism should encompass the karst pits in Trlji (Barban Municipality), Palijon (Marčana Municipality), Pucići (Žminj Municipality), the Gospetova or Goljeva karst pit (Sveta Nedelja Municipality), the Šuranska pit (on the border between the Tinjan Municipality and Pazin), Trogrlice (Kaštelir-Labinci Muncipalty), and the Semićki Abyss (Lupoglav Municpality). Deserted bauxite pits in the area of Pazin and Gračišće $\mathrm{Mu}-$ nicipality can be included as well. Although these između grada Rovinja i općine Vrsar, selo Tićan (općina Višnjan), selo Kućibreg na gornjoj Bujštini (Grad Buje), naselja na Ćićariji u općini Lanišće i gradu Buzetu te grad Labin i općina Raša. Punktovi ove rute povezani su javnim cestama, nalaze se u neposrednoj blizini smještajnih kapaciteta, a djelomice su povezani javnim međugradskim autobusnim prijevozom. Posebna je prednost ove rute $u$ tome što se ona svojim sjevernim i sjeveroistočnim dijelom može tematski nadovezati i spojiti s potencijalnim rutama memorijalnoga turizma u Sloveniji i Primorsko-goranskoj županiji.

Ruta masovnoga stradavanja stanovništva 1943. - 1945. Na ovoj ruti memorijalnoga turizma nalaze se punktovi na kojima se redovito održavaju službene komemoracije u sjećanje na stradalo civilno stanovništvo premda ti događaji za sada nemaju obilježja memorijalnoga turizma. Ruta spaja dijelove grada Pule sa selima Gajana na području grada Vodnjana, Šajini u općini Barban, Bokordići u općini Svetvinčenat, Kresini u općini Žminj, Zabrežani u široj okolici grada Pazina te selima na području gorja Ćićarija, na području grada Buzeta te općina Lanišće i Lupoglav. $\mathrm{Na}$ području navedenih gradova i općina nalaze se i drugi slični punktovi koji se mogu sadržajno uklopiti u ovu rutu. Isto tako, ova se ruta memorijalnoga turizma, poput prethodne, može tematski povezati s potencijalnom rutom koja bi uključivala selo Lipu (općina Matulji) u susjednoj Primorsko-goranskoj županiji.

Ruta krških i boksitnih jama 1943. - 1945. Obuhvaća one krške i boksitne jame u Istri koje su nedvojbeno označene kao mjesta stradavanja ljudi tijekom Drugoga svjetskog rata (Dukovski, 2001; Mikolić, 2003; Giron, 2004; Scotti, 2008; Pirjevec, 2009; Radošević, 2009). Ova tematska ruta memorijalnoga turizma obuhvatila bi krške jame Trlji (općina Barban), Palijon (općina Marčana), Pucići (općina Žminj), Gospetova ili Goljeva jama (općina Sveta Nedelja), Šuranska jama (na granici općine Tinjan i grada Pazina), Trogrlice (općina Kaštelir-Labinci) i Semićki ponor (općina Lupoglav). Također kao punktovi mogu biti uvrštene napuštene boksitne jame na području grada Pazina i općine Gračišće. Premda 
points are located close to tourist accommodation and public roads, their inclusion among memorial tourism thematic routes requires additional intervention; as was mentioned earlier, these routes are not connected to public roads for the most part, and are located in terrain which is difficult to reach and almost unapproachable. There are no markers or signs, and some of them remain unmarked even on the most recent topographic maps with the map scale $1: 25,000$, which are publicly accessible on the Geo-portal website of the State Geodetic Administration. The Semićki Abyss is an exception, although it is without signs and markers, and is located in the close proximity of the 5014-county road between Lanišće and Lupoglav.

Submarine visits to shipwrecks from WWI and WWII. The greatest advantage of this route is that submarine visits to shipwrecks are already included and recognised in Istria's tourist supply, and that there is abundant tourist accommodation nearby, as well as the relevant infrastructure (Gržinić and Zanketić, 2009). The most important points of the locations on the sea floor are near Plomin (Kršan Municipality), Ližnjan, Premantura (Medulin Municipality), as well as Rovinj and Novigrad. The relatively expensive equipment required for diving, as well as the necessary level of physical fitness and strenuous training (all necessary conditions for visits to submarine memorial tourism localities) are the main disadvantages of such routes.

There is the possibility for the inclusion, addition, and connection of all the memorial tourism routes mentioned here (as well as other part of the tourism supply) to pre-existing cultural routes in the region of Istrian towns and municipalities. Furthermore, memorial tourism routes can use, beside the network of public roads, pre-existing infrastructure and bicycle, motorcycle, and trekking routes. Moreover, memorial tourism thematic routes, taking into account experiences from abroad as well as experiences and practises by Istrian cultural routes, should be included in future spatial planning and strategic documents on the local and county level. se ovi punktovi nalaze blizu smještajnih kapaciteta i javnih cestovnih prometnica, njihovo uključivanje u tematsku rutu memorijalnoga turizma iziskuje dodatne intervencije. Naime, kao što je prethodno navedeno, ti punktovi najvećim dijelom nisu prometno povezani javnim cestama, nalaze se na vrlo teško prohodnu ili gotovo nepristupačnu terenu, bez oznaka i putokaza, a neki od njih nisu označeni ni na najnovijim službenim topografskim kartama u mjerilu 1:25000 koje su javno dostupne na Geoportalu Državne geodetske uprave. Izuzetak bi, premda bez oznaka i putokaza, bio Semićki ponor koji se nalazi neposredno uz županijsku cestu 5014 između Lanišća i Lupoglava.

Podmorski obilasci potopljenih brodova iz svjetskih ratova. Najveća je prednost ove rute da su podmorski obilasci potopljenih brodova već djelomice uključeni i prepoznati u turističkoj ponudi Istre te da se u blizini lokaliteta nalaze brojni smještajni kapaciteti te infrastruktura potrebna za ronilački oblik turizma (Gržinić i Zanketić, 2009). Najvažniji su punktovi lokacije na dnu mora u blizini naselja Plomin (općina Kršan), Ližnjan (istoimena općina), Premantura (općina Medulin) te gradova Rovinj i Novigrad. Relativno skupa ronilačka oprema, potrebna određena razina tjelesne pripremljenosti te specifična i zahtjevna obuka kao neophodni uvjeti potrebni za obilazak podmorskih lokaliteta memorijalnoga turizma glavni su nedostatci ove rute

$\mathrm{Za}$ sve predložene tematske rute memorijalnoga turizma, osim što mogu biti izdvojeni i samostalni segmenti turističke ponude, postoji mogućnost uključivanja, nadopunjavanja i spajanja s postojećim kulturnim rutama na područjima istarskih gradova i općina. Isto tako, memorijalne turističke rute mogu se, osim javnom cestovnom mrežom, koristiti izgrađenom infrastrukturom i mrežom već postojećih i turistički promoviranih biciklističkih, motociklističkih i pješačkih staza. U konačnici, tematske rute memorijalnoga turizma uvažavajući dosadašnja inozemna iskustva, ali $\mathrm{i}$ iskustva i prakse s istarskim kulturnim rutama, treba uvrstiti u buduće prostornoplanske i strateške dokumente na lokalnoj i županijskoj razini.
The potential of memorial tourism development in Istria (Croatia)

Potencijali razvoja memorijalnog turizma u Istri (Hrvatska) 


\section{Conclusion}

This research has clearly shown that, in the region of Istria's towns and municipalities, there are all six proposed types of potential memorial tourism sites from three major turning points in the $20^{\text {th }}$ century, and the most significant points have been identified as key in the formation of thematic routes of memorial tourism. All the potential sites of memorial tourism can be divided into those that are officially commemorated and are present in the media and those that include inaccessible and unmarked karst and bauxite pits that served as execution sites, but are without media presence, official visits, and commemoration. Taking similar experiences and examples of good practice from the nations and regions that are similar to Croatia in their historical and socio-economic development, six memorial tourism thematic routes have been proposed, and these would encompass all Istrian towns and municipalities. The advantage of these proposed routes is observable in their well-developed network of roads, plentiful tourist accommodation, and the presence of required infrastructure. Finally, memorial tourism routes can be implemented as an independent segment of Istria's tourism supply and can also find their place among pre-existing cultural routes, as well as among bicycle, motorcycle, and trekking routes.

The shortcomings of this work are due to the lack of time and the duration of fieldwork and participant observation, as well as in insufficient material and financial resources, and also in the persistent controversies concerning the events in the first half of the $20^{\text {th }}$ century connected to the collective memory of Istria's population. The aforementioned shortcomings did not, however, endanger the elaboration of the proposed methods, obtainment of research results, or the accomplishment of the proposed aims. Finally, the results of this paper can be used in future research concerning questions on the implementation of memorial tourism in Croatian tourism regions, and also as a scientific foundation for the elaboration of planning documents for units of local and regional government, with the aim of make this form of cultural tourism stand out.

\section{Zaključak}

Istraživanjem je nepobitno utvrđeno da se na područjima istarskih gradova i općina nalazi svih šest predloženih tipova potencijalnih lokaliteta memorijalnoga turizma iz triju prekretničkih povijesnih razdoblja prve polovice 20. stoljeća, a najznačajniji punktovi izdvojeni su kao ključni u oblikovanju tematskih ruta memorijalnoga turizma. Svi potencijalni lokaliteti memorijalnoga turizma mogu se podijeliti u one koji se službeno komemoriraju i medijski prate te one koji uključuju nepristupačne i neobilježene krške i boksitne jame kao mjesta stradavanja, ali bez medijskoga odjeka, službenih posjeta i komemoriranja. Uvažavajući slična iskustva i primjere dobre prakse iz država i regija koje su po svom povijesnom i društveno-ekonomskom razvoju slične Hrvatskoj, predloženo je šest tematskih ruta memorijalnoga turizma, a koje bi obuhvatile sve istarske gradove i općine. Prednost predloženih ruta ogleda se u vrlo dobro razvijenoj cestovnoj mreži, velikom broju smještajnih turističkih objekata te drugoj potrebnoj infrastrukturi. Konačno, rute memorijalnoga turizma mogu se uvrstiti kao samostalan dio ponude istarskoga turizma, ali se mogu uklopiti i u postojeće kulturne rute te biciklističke, motociklističke i pješačke staze.

Nedostatci ovoga rada proistječu iz ograničenoga vremena i trajanja terenskih istraživanja i sudioničkoga promatranja te nedostatnih materijalnih resursa i financijskih izvora, ali još uvijek prisutnih povijesno-političkih kontroverza o zbivanjima u prvoj polovici 20. stoljeća, povezanih s kolektivnom memorijom stanovništva Istre. No, navedeni nedostatci nisu ugrozili provedbu predloženih metoda, postizanje rezultata istraživanja i ostvarivanje postavljenih ciljeva. Unatoč navedenim nedostatcima rezultati ovoga rada mogu biti korišteni u budućim istraživanjima problematike implementacije memorijalnoga turizma u turističkim regijama Hrvatske, ali i kao znanstvena podloga u izradi planskih dokumenata jedinica lokalne i regionalne samouprave s ciljem konkretizacije ovoga oblika kulturno turističke ponude. 
Afrić Rakitovac, K., Urošević, N. (eds.), 2017: Models of Valorisation of Cultural Heritage in Sustainable Tourism, Juraj Dobrila University, Pula.

Afrić Rakitovac, K., Urošević, N., Vojnović, N., 2019: Creating Innovative Tourism Experiences Through Sustainable Valorisation of Archaeological Heritage, in: Zadel, Z., Smolčić Jurdana, D. (eds.), Tourism in Southern and Eastern Europe 2019 - Conference Proceedings, University of Rijeka, Faculty of Tourism and Hospitality Management, Opatija, 1-15, DOI:10.20867/tosee.05.28.

Bowman, M. S., Pezzullo, P. C., 2009: What's so 'Dark' about 'Dark Tourism'?: Death, Tours, and Performance, Tourist Studies 9 (3), 187-202, DOI: 10.1177/1468797610382699.

Brown, L., 2015: Memorials to the victims of Nazism: the impact on tourists in Berlin, Journal of Tourism and Cultural Change 13 (3), 244-260, DOI:10.1080/ 14766825.2014.946423.

Buršić, H., 2011: Od ropstva do slobode: Istra 1918-1945. Male bilješke o velikom putu, C.A.S.H, Pula.

Cherini, A., 1993: La tragedia del piroscafo lloydiano "Baron Gautsch" 13 agosto 1914, Associazione Marinara "Aldebaran", Trieste.

Cortini, L. (ed.), 2019: Dissonant Heritage: Wars and Ideologies of the 20th Century in Adriatic and Ionian Region, About the Project, https://dissonantheritage.wordpress.com/ (4.12. 2019.)

DeWalt, K. M., DeWalt, B. R., 2011: Participant Observation - A Guide for Fieldworkers, Rowman And Littlefield Publishers, Lanham.

Drndić, Lj., 1978: Orǔ̌je i sloboda Istre 1941. - 1943., Školska knjiga i Glas Istre, Zagreb i Pula.

Drvenkar, N, Banožic, M., Živić, D, 2015: Development of memorial tourism as a new concept - possibilities and restrictions, Tourism and Hospitality Management 21 (1), 63-77.

Državni zavod za statistiku (DZS)/Croatian Bureau of Statistics (CBS), 2019: Turizam u 2018/Tourism 2018, Statistička izvješča/Statistical reports 1639 , Zagreb.

Dujmović, M., 2019: Komercijalizacija kulturne baštine u turizmu, Socijalna ekologija 28 (2), 145-161, DOI:

\subsection{4/SocEkol.28.2.3}

Dukovski, D., 2001: Rat i mir istarski: model povijesne prijelomnice 1943.-1955., C.A.S.H., Pula.

Dukovski, D., 2011a: Povijest Pule; Deterministicki kaos i jahači Apokalipse, Nova Istra, Pula.

Dukovski, D., 2011b: Povijesna ekspertiza tragedije na pulskoj Vargaroli (Vergarolla) 18. kolovoza 1946., Histria 1 (1), 79112, DOI: 10.32728/h2011.04.

Facchinetti, V., 2019: Un silenzio pieno di parole, L'Arena di Pola, 31 October, 1-2.

Foley, M., Lennon, J., 1996: JFK and dark tourism: A fascination with assassination, International Journal of Heritage Studies 2 (4), 198-211, DOI: 10.1080/13527259608722175.

Foundations Walk of peace in Isonzo Valley, 2018: The Walk of peace from the Alps to the Adriatic, The heritage of history and nature, Kobarid.

Ghetau, L, Esanu, L. V., 2010: Dark tourism in Romania: from concept to reality, Sustainable Tourism IV Vol. 139, 581590, DOI:10.2495/ST100501.

González Vázquez, D., 2018: Dark tourism and memorial tourism: Nexus and divergences between theoretical models, European Journal of Tourism Research 20, 46-58.

Giron, A., 2004: Zapadna Hrvatska u Drugom svjetskom ratu, Adamić, Rijeka.

Grad Buje, 2019: 75. obljetnica bitke kod Kućibrega, https://www.buje.hr/hr/novosti/75--obljetnica-bitke-kod-kucibrega (29. 10. 2019.)

Gržinić, J., Zanketić, P., 2009: The Istrian Seabed - A Perspective of Sustainable Tourism Development, Pomorstvo 23 (1), 199-219.

Gržinić, J. Vodeb, K. (eds.), 2015: Cultural tourism and destination impacts, Juraj Dobrila University, Pula.

Hall, C. M. (ed.), 2011: Fieldwork in Tourism: Methods, Issues and Reflections, Routledge, London-New York.

Halmi, A., 2005: Strategije kvalitativnih istraživanja u primijenjenim društvenim znanostima, Naklada Slap, Jastrebarsko.

Hartmann, R., 2014: Dark tourism, thanatourism, and dissonance in heritage tourism management: new directions in contemporary tourism research, Journal of Heritage Tourism 9 (2), 166-182, DOI: 10.1080/1743873X.2013.807266

Hertzog, A., 2016: Re-inventing battlefield tourism? In times of peace: Connecting tourism and the remembrance of violence, in: Andrews, H. (ed.), Tourism and violence, Routledge, London and New York, 85-102.

Horodnikova, J., Derco, J., 2015: Dark tourism, thematic routes and possibilities for innovation in the Slovak Republic, Tourism 63 (2), 241-246.

Irimiás, A., 2014: The Great War heritage site management in Trentino, northern Italy, Journal of Heritage Tourism, 9 (4), 317-331, DOI: 10.1080/1743873X.2014.908886

Ivandić, N., Telišman-Košuta, N., Čorak, S., Krešić, D. 2006: Ljetni odmorišni turizam, in: Čorak, S., Mikačić, V. (eds.): Hrvatski turizam: plavo, bijelo, zeleno, Institut za turizam, Zagreb, 1-38.

Jacobsen, J. S., 2007: Use of Landscape Perception Methods in Tourism Studies: A Review of Photo-Based Research Approaches, Tourism Geographies 9 (3), 234-253, DOI: $10.1080 / 14616680701422871$

Kalmeta, R., 1981: O nazivima turist, turizam i turizmologija, Jezik: časopis za kulturu hrvatskoga književnog jezika 29 (2), 48-52.

Kennell, J., Šuligoj, M., Lesjak, M., 2018 : Dark Events: Commemoration and Collective Memory in the Former Yugoslavia, Event Management 22 (6), 945963, DOI: $10.3727 / 152599518 \times 153461$ 32863247

Kesar, O., Tomas, P., 2014: Obilježja i dosezi memorijalnog turizma u Hrvatskoj, Liburna 3 (1), 49-88.

Kešac, G., Skuljan Bilić, L. (eds.), 2018: Sloboda narodu!' Antifasizizam u Istri, Povijesni i pomorski muzej Istre, Pula

Lennon, J., Foley, M., 2000: Dark tourism: The attraction of death and disaster, Continuum, London.

Liyanage, S., Coca-Stefaniak. A., Powell, R., 2015: Dark destinations - visitor reflections from a holocaust memorial site, International Journal of Tourism Cities 1 (4), 282-298, DOI: 10.1108/IJTC-082015-0019

Mikolić, M., 1973: Istra 1943, Časopis za suvremenu povijest 5 (3), 53-69.
The potential of memorial tourism development in Istria (Croatia)

Potencijali razvoja memorijalnog turizma u Istri (Hrvatska)

\section{Literature} Literatura 
GEOGRAFSKI

GLASNIK

82/2,107-129 (2020.)
Mikolić, M., 2003: Istra 1941.-1947.: godine velikih preokreta, Barbat, Zagreb.

Minić, N., 2012: Development of 'dark' tourism in the contemporary society, Zbornik radova Geografskog instituta Jovan Crijić 62 (3), 81-103, DOI 10.2298/IJGI1203081M.

Mionel, V., 2019: Dark tourism and thanatourism: Distinct tourism typologies or simple analytical tools? Tourism 67 (4), 423-437.

Mrđen, N., 2017: Pula's fortifications - a strategy of sustainable use, in: Afrić Rakitovac, K., Urošević, N. (eds.), Models of Valorisation of Cultural Heritage in Sustainable Tourism, Juraj Dobrila University, Pula, 169-184.

Nauert S., 2017: The Linguistic and Cultural Interpretation of Dissonant Heritage: the ATRIUM Cultural Route, Almatourism 15, 16-37, DOI: 10.6092/ issn.2036-5195/6807.

Novak, R. (ed.), 2020: Waste in Karst Underground, http://cistopodzemlje.info/ en/o-nama/o-otpadu-u-podzemlju/ (5. 2. 2020.).

Njegač, D., Pejnović, D., Stanišić, S., 2010: Prometni sustav Istre - razvoj i problemi integriranja u prometni sustav Hrvatske, Acta Geographica Croatica 37, 5-22.

Opačić, V. T., 2003: Domovinski rat kao osnova razvoja memorijalnog turizma Hrvatske?!, http://www.geografija.hr/ hrvatska/domovinski-rat-kao-osnova-razvoja-memorijalnog-turizma-hrvatske/ (7. 2. 2019.).

Orlić, I., 2019: Autentičnost ponude istarskoga turizma - stanovanje, in: Povolo, C., Križman Pavlović, D., Novak, M., Orbanić E. (eds.), Zbornik radova 2. međunarodnog znanstvenog skupa Istarsko gospodarstvo jučer i sutra, Državni arhiv u Pazinu, Sveučilište Jurja Dobrile u Puli, Università Ca' Foscari Venezia, 204-212.

Phillips, R., Johns, J., 2012: Fieldwork for Human Geography, SAGE, London.

Pirjevec, J. (ed.), 2009: Foibe Una storia d 'Italia, Giulio Einaudi, Torino.

Radošević, M., 2009: Pregled izvještaja pulskog dnevnika Corriere Istriano (listopad-prosinac 1943.) o stradalima u istarskim fojbama i boksitnim jamama nakon kapitulacije Italije 8. rujna 1943. godine, Problemi sjevernog Jadrana 10, 89-107.
Raine, R., 2013: A dark tourism spectrum, International Journal of Culture, Tourism and Hospitality Research 7 (3), 242-256, DOI: 10.1108/ IJCTHR-05-2012-0037.

Rakić, T., Chambers, D. (eds.), 2012: An Introduction to Visual Research Methods in Tourism, Routledge, London-New York.

Ribeiro, N. F., Foemmel, E. W., 2012: Participant observation, in: Dwyer, L., Gill, A., Seetaram, N. (eds.), Handbook of Research Methods in Tourism Quantitative and Qualitative Approaches, Edward Elgar, Cheltenham, 377-391.

Rnjak, G., Ciceran, A., Zrnčić, V., Županić, K., Glavaš, I., Rnjak, D., 2017: Speleološka istraživanja na području Labinštine u Istri, Subterranea Croatica 15 (1), 24-49.

Rojek, C., 1993: Ways of escape: Modern transformations in leisure and travel, Macmillan, Basingstoke.

Ružić, P., Medica, I., 2010: Tradicijski seoski identitet Istre - njegovo prepoznavanje i uključivanje u turistički proizvod, Sociologija i prostor 48 (3), 479-504.

Scotti, G., 2008: Krik iz fojbe, Adamić, Rijeka.

Seaton, A. V., 1996: Guided by the dark: From thanatopsis to thanatourism, International Journal of Heritage Studies 2(4), 234-244, DOI 10.1080/13527259608722178.

Seaton, A. V., 2000: "Another Weekend away Looking for Dead Bodies...": Battlefield Tourism on the Somme and in Flanders, Tourism Recreation Research 25 (3), 63-77, DOI 10.1080/02508281.2000.11014926.

Seaton, A. V., 2002: Thanatourism's final frontiers? Visits to cemeteries, churchyards and funerary sites as sacred and secular pilgrimage, Tourism Recreation Research 27 (2), 73-82, DOI $10.1080 / 02508281.2002 .11081223$

Sharpley, R., Stone, P. R. (eds.), 2009: The Darker Side of Travel: The Theory and Practice of Dark tourism, Channel View Publication, Bristol.

Stone, P., 2006: A dark tourism spectrum: Towards a typology of death and macabre related tourist sites, attractions and exhibitions, Tourism 54 (2), 145-160.

Stone, P., 2012: Dark tourism and significant other death: towards a Model of
Mortality Mediation, Annals of Tourism Research 39 (3), 1556-1587, DOI: 10.1016/j.annals.2012.04.007.

Stone, P., Sharpley, R., 2008: Consuming dark tourism: A Thanatological Perspective, Annals of Tourism Research, 35 (2), 574-595, DOI: 10.1016/j.annals.2008.02.003.

Šuligoj, M., 2016: Memories of War and Warfare Tourism in Croatia, Annales, Series Historia et Sociologia, 26 (2), 259270, DOI: 0.10.19233.ASHS.2016.20.

Šuligoj, M., 2017a: Svijetle i tamne strane mračnog turizma u Sloveniji, in: Drešković, N. (ed.), Zbornik radova četvrtog kongresa geografa Bosne i Hercegovine, Geografsko društvo u Federaciji Bosne i Hercegovine, Sarajevo, 799-809.

Šuligoj, M., 2017b: Warfare tourism: an opportunity for Croatia?, Economic Research-Ekonomska Istraživanja, 30 (1), 439-452, DOI: 10.1080/1331677X.2017.1305800.

Šuligoj, M., 2019: Dark Events of the Istrian Countryside: An Electronic Media Perspective, Academica Turistica 12 (2), 121-132, DOI: 10.26493/23354194.12.121-132.

Tizzoni, E., 2013: La memoria della grande guerra nei musei trentini tra cultura e turismo, Casopis za povijest $\mathrm{Za}$ padne Hrvatske 8, 179-192.

Tunbridge, J., Ashworth, G., 1996: Dissonant heritage: The management of the past as a resource in conflict, Wiley, Chichester and New York.

Turistička zajednica Istarske županije (TZIŽ)/ Istria Tourist Board (ITB), 2014: Master plan turizma Istarske županije 2015. - 2025. / Istrian County Tourism Master Plan 2015 - 2025 , Poreč.

Virgili, S., Delacour, H., Bornarel, F., Liarte, S., 2018: "From the Flames to the Light": 100 years of the commodification of the dark tourist site around the Verdun battlefield, Annals of Tourism Research 68, 61-72, DOI: 10.1016/j.annals.2017.11.005.

Vojnović, N., 2016: Terenska istraživanja u metodološkom sustavu turističke geografije/Field Research in the Methodological System of Tourism Geography, Hrvatski geografski glasnik 78 (1), 97-123. DOI: 10.21861/HGG.2016.78.01.05. 
Vukojević, K., Opačić, V. T., 2017: Memorial tourism in Croatia? A case study of Vukovar: attitudes of local population, in: Drešković, N. (ed.), Book of proceedings of 2nd International Tourism and Hospitality Management Conference, 2 (2), Faculty of Science, University of Sarajevo, Sarajevo, 73-89.

Wight, A. C., 2006: Philosophical and methodological praxes in dark tourism: Controversy, contention and the evolving paradigm, Journal of Vacation Marketing 12 (2), 119-129, DOI: $10.1177 / 1356766706062151$.

Web sites of Istrian municipalities and towns

Web sites of Istrian municipal and towns' tourist boards
Winter, C., 2011: First World War Cemeteries: Insights from Visitor Books, Tourism Geographies 13 (3), 462-479, DOI: 10.1080/14616688.2011.575075.

Wolaston, I., 2005: Negotiating the marketplace: The role(s) of Holocaust museums today, Journal of Modern Jewish Studies 4 (1), 63-80, DOI: 10.1080/14725880500052782
The potential of memorial tourism development in Istria (Croatia)

Potencijali razvoja memorijalnog turizma u Istri

(Hrvatska) 